\title{
Alfalfa baleage with increased concentration of nonstructural carbohydrates supplemented with a corn-based concentrate did not improve production and nitrogen utilization in early lactation dairy cows
}

\author{
A. F. Brito, ${ }^{*}$ G. F. Tremblay, $†$ A. Bertrand,† Y. Castonguay,† G. Bélanger,† R. Michaud,† C. Lafrenière,‡ \\ R. Martineau, $\S$ and R. Berthiaume\# ${ }^{1}$ \\ *University of New Hampshire, Department of Biological Sciences, Durham 03824 \\ †Soils and Crops Research and Development Centre, Agriculture and Agri-Food Canada, Québec City, QC, Canada G1V 2J3 \\ ‡Université du Québec en Abitibi-Témiscamingue, Rouy-Noranda, QC, Canada J9X 5E4 \\ $\S$ Dairy and Swine Research and Development Centre, Agriculture and Agri-Food Canada, Sherbrooke, QC, Canada J1M 1 Z3 \\ \#Valacta, Dairy Production Centre of Expertise Québec-Atlantic, Sainte-Anne-de-Bellevue, QC, Canada H9X 3R4
}

\begin{abstract}
The objective of this study was to investigate the effects of feeding alfalfa baleage with different concentrations of nonstructural carbohydrates (NSC) supplemented with a common corn-based concentrate on performance, ruminal fermentation profile, $\mathrm{N}$ utilization, and omasal flow of nutrients in dairy cows during early lactation. Ten multiparous (8 ruminally cannulated) and 8 primiparous Holstein cows were randomly assigned to treatments (high- or low-NSC diet) in a crossover design. The difference in NSC concentration between the 2 alfalfa baleages fed from d 14 to 21 averaged $14 \mathrm{~g}$ of NSC/kg of dry matter (DM). Forages and concentrate were offered in separate meals with forages fed once and concentrate offered 3 times daily. Except for the molar proportion of valerate, which was lowest in cows fed the high-NSC diet, no other changes in ruminal fermentation were observed. Omasal flows of most nitrogenous fractions, including bacterial nonammonia $\mathrm{N}$ and $\mathrm{AA}$, were not affected by treatments. Apparent ruminal digestibilities of neutral and acid detergent fiber and $\mathrm{N}$ were lowest, whereas that of total ethanol-soluble carbohydrates was highest when feeding the high-NSC diet. Postruminal digestibilities of DM, organic matter, fiber, and $\mathrm{N}$ were highest in cows fed the high-NSC diet, resulting in no difference in total-tract digestibilities. Total-tract digestibility of total ethanol-soluble carbohydrates was highest in cows fed the high-NSC diet, but that of starch did not differ across treatments. Although milk yield and total DM intake did not differ between treatments, yields of milk fat and $4 \%$ fat-corrected milk decreased significantly in cows fed the high-NSC diet. Milk concentration of urea $\mathrm{N}$ was lowest, and that of ruminal $\mathrm{NH}_{3}-\mathrm{N}$ highest, in
\end{abstract}

Received July 26, 2013.

Accepted July 14, 2014.

${ }^{1}$ Corresponding author: rberthiaume@valacta.com cows fed the high-NSC diet. Plasma urea N concentration tended to be decreased in cows fed the high-NSC diet, but concentrations of AA were not affected by treatments, with the exception of Asp and Cys, both of which were lowest in cows fed the low-NSC diet. Feeding diets with contrasting NSC concentrations did not improve milk production, $\mathrm{N}$ utilization, or bacterial protein synthesis, possibly because intakes of NSC and DM were similar between treatments. Overall, results from the current study should be interpreted cautiously because of the lack of difference in dietary NSC intake between treatments and reduced $\mathrm{N}$ and fiber intakes when feeding the high-NSC diet.

Key words: alfalfa baleage, dairy cow, milk production, nonstructural carbohydrate

\section{INTRODUCTION}

The need to reduce the environmental impact (e.g., nitrate leaching and nitrous oxide emissions) of dairy farming while improving water and air quality has prompted the dairy industry across North America to develop feeding strategies to enhance $\mathrm{N}$ utilization in lactating dairy cows. In general, forage sources are rich in RDP but poor in NSC, leading to unbalanced supplies of $\mathrm{NH}_{3}-\mathrm{N}$ and fermentable energy in the rumen. Diurnal variation in the concentration of NSC in alfalfa (Medicago sativa L.) is well documented (Burns et al., 2005; Brito et al., 2008; Morin et al., 2011). Carbon fixation occurs at a greater rate than carbon exportation during daylight, resulting in the accumulation of NSC in plant tissues as the day progresses (Brito et al., 2008; Morin et al., 2011; Yari et al., 2012a). Previous studies have indicated that compared with a.m.-cut alfalfa baleage (low NSC), p.m.-cut alfalfa baleage (high NSC) fed to late-lactation dairy cows significantly increased DMI $(+5 \%)$, ECM $(+8 \%)$, milk $\mathrm{N}$ efficiency $(+8 \%)$, and bacterial protein synthesis $(+7 \%$; Brito et al., 2008, 2009). In addition, Berthiaume et al. (2010) observed 
a significant increase in the flow of bacterial protein $(+14 \%)$ when feeding high-NSC alfalfa genotypes during continuous culture fermentation. Therefore, increasing the concentration of NSC to balance the supplies of RDP and ruminal fermentable energy enhanced N utilization when conserved (i.e., baleage) or fresh alfalfa was fed as the sole dietary source (Brito et al., 2008, 2009; Berthiaume et al., 2010). However, typical dairy rations fed in North America are formulated to include high levels of concentrate $(\geq 50 \%)$, with most of the grain energy source provided by corn (NRC, 2001; Krause and Oetzel, 2006). This is in contrast to the low proportion $(\leq 23 \%)$ of dietary concentrate (Miller et al., 2001; Moorby et al., 2006) or no concentrate used (Brito et al., 2008, 2009) when cows were fed high-NSC forages in previous experiments. Thus, research to investigate how supplementation of high-NSC forage with the amounts of concentrate typically found in North American dairy rations may modulate milk production and nutrient utilization responses in dairy cows during early lactation is lacking. Recently, Yari et al. (2014) reported no effect on DMI and milk production but $\mathrm{N}$ efficiency (fecal N:milk $\mathrm{N}$ ratio) and nutrient digestibility were improved in early-lactation dairy cows fed TMR containing (DM basis) $20 \%$ of p.m.- versus a.m.cut alfalfa hay, $15 \%$ barley silage, and $65 \%$ concentrate. These results indicate that despite improved nutrient digestibility and $\mathrm{N}$ efficiency, milk production did not respond positively in cows fed p.m.-cut alfalfa hay (Yari et al., 2014), thus warranting further research.

We hypothesized that, compared with a diet containing alfalfa baleage with lower concentration of NSC, a diet containing alfalfa baleage with higher concentration of NSC would increase intakes of DM and ruminal fermentable energy, ultimately improving milk yield and $\mathrm{N}$ utilization in dairy cows during early lactation. The objective of the current study was to evaluate the effects of 2 dietary concentrations of NSC on nutrient intake and utilization, milk production, ruminal metabolism, and omasal flow of nutrients in dairy cows during early lactation.

\section{MATERIALS AND METHODS}

Care and handling of the animals used in the current experiment were conducted as outlined in the guidelines of the Canadian Council on Animal Care (1993). This study was approved by the Institutional Animal Care Committee of the Dairy and Swine Research and Development Centre (Sherbrooke, QC, Canada).

\section{Alfalfa Harvest}

The alfalfa ('AC Caribou') used in the current study was grown in 3 pure stand fields (total of 14 ha) located at the Agriculture and Agri-Food Canada Normandin Research Farm in Normandin $\left(48^{\circ} 51^{\prime} \mathrm{N}, 72^{\circ} 32^{\prime} \mathrm{W}\right)$, Québéc, Canada. The summer regrowth of half of each alfalfa field was cut on August 19, 2008, at sundown (between 1800 and 2000 h; p.m.-cut alfalfa) following a partly sunny day (daily global radiation of $21.3 \mathrm{MJ} / \mathrm{m}^{2}$ compared with a maximum of $28.8 \mathrm{MJ} / \mathrm{m}^{2}$ previously observed at this location). The second half of each field was cut on August 20, 2008, at sunup (between 0600 and 0900 h; a.m.-cut alfalfa). Alfalfa from all fields was cut at the full flowering stage of development, yielding approximately $1.5 \mathrm{t}$ of DM/ha. Forage was cut using a conventional mower conditioner, tedded, and fieldwilted to about $430 \mathrm{~g}$ of $\mathrm{DM} / \mathrm{kg}$ of fresh matter, which was attained at approximately 1100 and $1300 \mathrm{~h}$ on August 21 for p.m.- and a.m.-cuts, respectively. Between 1230 and $1700 \mathrm{~h}$ in the afternoon of August 21, 2008, p.m.- and then a.m.-cut alfalfas were harvested as baleage using a large rectangular baler (New Idea model 7333; Agco Corporation, Duluth, GA) and wrapped with stretch plastic using a bale wrapper (model 680S, Équipement Anderson, Chesterville, QC, Canada). Minimum and maximum air temperatures were, respectively, 7.9 and $15.8^{\circ} \mathrm{C}$ on August $19,7.4$ and $18.0^{\circ} \mathrm{C}$ on August 20, and 9.5 and $26.3^{\circ} \mathrm{C}$ on August 21, 2008. A total of 114 bales (54 p.m.-cut and 60 a.m.-cut) were made and later transported to the Dairy and Swine Research and Development Centre of Agriculture and Agri-Food Canada located in Sherbrooke $\left(45^{\circ} 24^{\prime} \mathrm{N}\right.$, $71^{\circ} 54^{\prime} \mathrm{W}$ ), Québéc, Canada for the animal study. The time elapsed between alfalfa baling and feeding to the cows (d 1 of the study) was approximately $72 \mathrm{~d}$.

\section{Animals, Experimental Design, and Diets}

Ten (8 ruminally cannulated) multiparous Holstein cows averaging (mean $\pm \mathrm{SD}$ ) $44 \pm 26$ DIM, $626 \pm$ $56 \mathrm{~kg}$ of BW, $4.0 \pm 1.07 \mathrm{yr}$ of age, and $2.7 \pm 0.95$ parities, and 8 primiparous Holstein cows averaging 50 \pm 9 DIM, $524 \pm 60 \mathrm{~kg}$ of BW, and $2.2 \pm 0.11 \mathrm{yr}$ of age at the beginning of the experiment were blocked by DIM, milk yield, and parity. Within each block, cows were randomly assigned to 2 treatments (highor low-NSC diet) in a crossover design. Each period lasted $21 \mathrm{~d}$ (total of $42 \mathrm{~d}$ ) and consisted of $14 \mathrm{~d}$ for diet adaptation and $7 \mathrm{~d}$ for data and sample collection. Each pair of baleages (pairing methodology described in the next section) was fed ad libitum to the cows once daily at approximately $0900 \mathrm{~h}$. The nutrient composition of baleages is presented in Tables 1, 2, and 3. The daily concentrations of NSC of each pair of baleages fed during the sampling weeks (d 14 to 21) are shown in Figure 1. A common corn-based concentrate was top dressed 3 times daily $(1000,1500$, and $2000 \mathrm{~h}$ ) in 
equal portions to minimize the risk of ruminal acidosis and other digestive upsets. The following ingredients were used in the concentrate (\% as fed): cracked corn (80.3\%), chemically treated soybean meal (13.8\%; Top Soy; Shur-Gain, Brossard, QC, Canada), and a mineral plus vitamin premix $(5.9 \%)$. The nutrient composition of the concentrate is presented in Tables 1, 2, and 3 . The mineral plus vitamin premix provided (per $\mathrm{kg}$ of premix DM): $2.43 \mathrm{~g}$ of $\mathrm{Ca}, 2.38 \mathrm{~g}$ of $\mathrm{P}, 2.23 \mathrm{~g}$ of $\mathrm{Mg}$, $9.98 \mathrm{~g}$ of Na, $5.53 \mathrm{~g}$ of $\mathrm{Cl}, 1.98 \mathrm{~g}$ of $\mathrm{Fe}, 2.24 \mathrm{~g}$ of $\mathrm{Zn}$, $1.50 \mathrm{~g}$ of Mn, $449 \mathrm{mg}$ of $\mathrm{Cu}, 44.9 \mathrm{mg}$ of I, $16.5 \mathrm{mg}$ of Co, $13.4 \mathrm{mg}$ of Se, $46.2 \mathrm{mg}$ of K, $69.4 \mathrm{mg}$ of S, 202,000 IU of vitamin A, 44,000 IU of vitamin D, and 1,140 IU of vitamin E. Orts were collected daily at $0800 \mathrm{~h}$, and the amount of feed offered to the cows was adjusted daily to yield refusals equal to approximately 5 to $10 \%$ of intake. Cows were housed in a tie stall barn and had free access to water throughout the experiment.

\section{Bales Ranking and Feed Sampling and Analyses}

A ranking and pairing procedure was developed to obtain, as much as possible, a consistent difference in NSC concentration between the high- and low-NSC baleages throughout the experiment (Brito et al., 2008). Approximately 3 to 4 cores were made in each bale (n $=114$ ) using an electric drill fitted with a metal core sampler 1 mo before the beginning of the experiment (approximately 6 wk after baling), with all cores composited to yield individual 200-g sample sizes. Samples were then lyophilized, ground to pass through a 1-mm screen (Wiley mill, Arthur H. Thomas, Philadelphia, PA), and individually analyzed for total reducing sugars (sucrose, glucose, and fructose), pinitol, and starch. Pinitol is a cyclitol nonreducing sugar (Streeter et al., 2001) found in several legume species (Smith and Phillips, 1980) and possibly involved in plants' survival against adverse environmental conditions (McManus et al., 2000; Streeter et al., 2001), including freezing stress (Bertrand et al., 2007). Water-soluble carbohydrates (WSC) were calculated by combining reducing sugars and pinitol, whereas NSC was obtained by adding WSC plus starch (Table 1). To rank and pair bales, the NSC concentration of all 114 bales was recorded. Second, bales were ranked from the highest to the lowest NSC concentration. Third, the high-NSC bale with highest NSC concentration was paired with the low-NSC bale with highest NSC concentration; this pairing procedure was repeated to create 42 pairs that were randomly assigned to each of the 42 experimental days.

It is important to note, however, that the NSC concentration of the p.m.-cut alfalfa baleage was not consistently higher than that of the a.m.-cut alfalfa baleage, in contrast to previous observations (Brito et al., 2008),

Table 1. Concentrations of NSC and NSC fractions ( $\mathrm{g} / \mathrm{kg}$ of DM, unless otherwise noted) in alfalfa baleages and concentrate used during the sampling weeks in periods 1 and 2

\begin{tabular}{|c|c|c|c|c|c|}
\hline \multirow[b]{2}{*}{ Item } & \multicolumn{2}{|c|}{ Alfalfa baleage $^{1}$} & \multirow[b]{2}{*}{$\mathrm{SED}^{2}$} & \multirow[b]{2}{*}{$P$-value ${ }^{3}$} & \multirow[b]{2}{*}{ Concentrate } \\
\hline & High NSC & Low NSC & & & \\
\hline $\mathrm{DM}, \mathrm{g} / \mathrm{kg}$ of fresh matter & 468 & 444 & 17.2 & 0.17 & 890 \\
\hline Sucrose & 1.1 & 0.79 & 0.20 & 0.20 & 15.6 \\
\hline Glucose & 13.3 & 7.7 & 1.4 & $<0.001$ & 3.2 \\
\hline Fructose & 11.2 & 5.7 & 1.2 & $<0.001$ & 0.51 \\
\hline Total reducing sugars ${ }^{5}$ & 25.5 & 14.2 & 2.6 & $<0.001$ & 19.3 \\
\hline Pinitol & 9.1 & 8.2 & 0.49 & 0.08 & 3.7 \\
\hline $\mathrm{WSC}^{6}$ & 34.5 & 22.4 & 2.8 & $<0.001$ & 22.9 \\
\hline $\operatorname{Starch}^{7}$ & 8.5 & 6.8 & 0.45 & $<0.001$ & 616 \\
\hline NSC (WSC + starch) & 43.0 & 29.1 & 3.0 & $<0.001$ & 639 \\
\hline TESC $^{8}$ & 37.8 & 26.7 & 2.9 & $<0.001$ & 33.4 \\
\hline Starch $^{9}$ & 7.8 & 5.7 & 0.53 & $<0.001$ & 522 \\
\hline NSC (TESC + starch) & 45.6 & 32.3 & 3.1 & $<0.001$ & 555 \\
\hline
\end{tabular}

${ }^{1}$ High- and low-NSC alfalfa baleages were analyzed individually for DM and NSC fractions in samples collected from d 14 to 21 in each period ( $\mathrm{n}=8$ samples/treatment).

${ }^{2} \mathrm{SED}=$ standard error of the LSM difference.

${ }^{3}$ Two-sample $t$-test for probability of treatment effect (high- vs. low-NSC alfalfa baleage).

${ }^{4}$ Samples of concentrate used for NSC and NSC fractions presented in this table were pooled from d 15 to 21 in each period.

${ }^{5}$ Total reducing sugars $=$ sucrose + glucose + fructose.

${ }^{6} \mathrm{WSC}$ (water-soluble carbohydrates) = total reducing sugars + pinitol.

${ }^{7}$ Analyzed as glucose equivalent using $p$-hydroxybenzoic acid hydrazide after sample extraction with methanol (Bertrand et al., 2007).

${ }^{8} \mathrm{TESC}=$ total ethanol soluble-carbohydrates.

${ }^{9}$ Analyzed as glucose equivalent using oxidase-peroxidase after sample extraction with ethanol (Hall, 2000). 
Table 2. Nutrient composition ( $\mathrm{g} / \mathrm{kg}$ of $\mathrm{DM}$, unless otherwise noted) and fermentation profile of alfalfa baleages and concentrate used during the sampling weeks in periods 1 and 2

\begin{tabular}{|c|c|c|c|c|c|}
\hline \multirow[b]{2}{*}{ Item } & \multicolumn{2}{|c|}{ Alfalfa baleage $^{1}$} & \multirow[b]{2}{*}{$\mathrm{SED}^{2}$} & \multirow[b]{2}{*}{$P$-value ${ }^{3}$} & \multirow[b]{2}{*}{ Concentrate } \\
\hline & High NSC & Low NSC & & & \\
\hline $\mathrm{pH}$ & 5.9 & 5.8 & 0.06 & 0.29 & $\mathrm{NA}^{5}$ \\
\hline $\mathrm{OM}$ & 902 & 889 & 3.8 & $<0.01$ & 942 \\
\hline $\mathrm{CP}$ & 165 & 170 & 3.1 & 0.08 & 125 \\
\hline Soluble $\mathrm{CP},{ }^{6} \%$ of $\mathrm{CP}$ & 43.7 & 45.0 & 1.2 & 0.31 & 69.5 \\
\hline NDIN, $\%$ of total N & 11.9 & 11.9 & 0.59 & 0.98 & 5.0 \\
\hline ADIN, $\%$ of total $\mathrm{N}$ & 8.7 & 8.0 & 0.32 & 0.04 & 3.8 \\
\hline $\mathrm{NDF}$ & 432 & 437 & 8.5 & 0.57 & 102 \\
\hline $\mathrm{ADF}$ & 386 & 389 & 6.2 & 0.69 & 36.1 \\
\hline Hemicellulose $^{7}$ & 46.2 & 48.5 & 6.3 & 0.72 & 66.3 \\
\hline Crude fat & 26.0 & 25.3 & 0.11 & 0.50 & 23.1 \\
\hline $\operatorname{Lignin}^{8}$ & 79.0 & 82.8 & 2.3 & 0.10 & 47.6 \\
\hline $\mathrm{Ca}^{8}$ & 15.4 & 14.7 & 0.26 & 0.01 & 0.43 \\
\hline $\mathrm{P}^{8}$ & 3.6 & 3.9 & 0.07 & $<0.001$ & 2.4 \\
\hline$K^{8}$ & 34.1 & 37.2 & 0.71 & $<0.001$ & 4.3 \\
\hline $\mathrm{Mg}^{8}$ & 3.1 & 3.1 & 0.04 & 0.54 & 1.2 \\
\hline Organic acids ${ }^{9}$ & 15.4 & 21.5 & 2.9 & 0.05 & NA \\
\hline Lactic acid & 9.3 & 12.7 & 2.6 & 0.21 & NA \\
\hline Lactic acid, $\%$ of total acids & 56.0 & 50.1 & 7.1 & 0.41 & NA \\
\hline Acetic acid & 5.2 & 7.5 & 1.0 & 0.03 & NA \\
\hline Propionic acid & 0.30 & 0.52 & 0.06 & $<0.01$ & NA \\
\hline Butyric acid & 0.06 & 0.06 & 0.04 & 0.98 & NA \\
\hline Isobutyric acid & 0.13 & 0.18 & 0.03 & 0.07 & NA \\
\hline Valeric acid & 0.25 & 0.27 & 0.03 & 0.51 & NA \\
\hline Isovaleric acid & 0.16 & 0.24 & 0.07 & 0.32 & NA \\
\hline Ethanol & 1.65 & 1.10 & 0.37 & 0.13 & NA \\
\hline
\end{tabular}

${ }^{1}$ High- and low-NSC alfalfa baleages were analyzed individually for nutrients in samples collected from d 15 to 21 in each period ( $\mathrm{n}=7$ samples/treatment).

${ }^{2} \mathrm{SED}=$ standard error of the LSM difference.

${ }^{3}$ Two-sample $t$-test for probability of treatment effect (high- vs. low-NSC alfalfa baleage).

${ }^{4}$ Samples of concentrate used for chemical analyses of variables presented in this table were pooled from d 15 to 21 in each period.

${ }^{5} \mathrm{NA}=$ not analyzed

${ }^{6}$ Soluble CP was determined using borate-phosphate buffer according to the methodology of Licitra et al. (1996).

${ }^{7}$ Hemicellulose $=\mathrm{NDF}-\mathrm{ADF}$.

${ }^{8}$ Lignin, Ca, P, K, and $\mathrm{Mg}$ were analyzed using near-infrared reflectance spectroscopy (Agri-Analyze; Sherbrooke, QC, Canada).

${ }^{9}$ Organic acids $=$ lactic acid + acetic acid + propionic acid + butyric acid + isobutyric acid + valeric acid + isovaleric acid.

thus resulting in the following feeding protocol during the 2 sampling weeks. At 7 feeding events (i.e., d 15 and 18 in period 1 and $\mathrm{d} 14,16,19,20$, and 21 in period 2), cows on the high-NSC diet were offered p.m.-cut alfalfa baleage, whereas those on the low-NSC diet received a.m.-cut alfalfa baleage. At 6 feeding events (i.e., d 14, 16,17 , and 20 in period 1 and $d 17$ and 18 in period 2 ), all cows in both treatments were offered a.m.-cut alfalfa baleage. At 2 feeding events (i.e., d 19 in period 1 and d 15 in period 2), all cows were offered p.m.-cut alfalfa baleage, and at 1 feeding event (i.e., d 21 in period 1) cows fed the high-NSC diet received a.m.cut alfalfa baleage, whereas those fed the low-NSC diet received p.m.-cut alfalfa baleage. It is also important to note that immediately before feeding on d 14 to 21 in each period, the daily assigned bales were re-cored as described earlier, with samples analyzed for individual sugars and starch. Interestingly, the average concentration of NSC decreased $(P<0.001$; data not shown $)$ by $54 \%$ in the high-NSC alfalfa baleage (from $66.3 \pm 5.5$ to $43.0 \pm 10.0 \mathrm{~g} / \mathrm{kg}$ of DM) and by $30 \%$ in the low-NSC alfalfa baleage (from $37.8 \pm 4.9 \mathrm{~g} / \mathrm{kg}$ of DM to 29.1 $\pm 6.1 \mathrm{~g} / \mathrm{kg}$ of DM) during the time between the first (i.e., 1 mo before the beginning of the experiment) and second (i.e., d 14 to 21 in each period) core samplings. Because pairing and assignments to each experimental day were based on NSC analyses conducted 1 mo before the beginning of the experiment, these unexpectedly large losses in NSC not only reduced the concentration of NSC in alfalfa baleage but also narrowed the differences in NSC between treatments (Figure 1). In addition, 4 bales had to be discarded due to visually ap- 
Table 3. Amino acid composition $(\mathrm{g} / \mathrm{kg}$ of $\mathrm{DM})$ of alfalfa baleages and concentrate used during the sampling weeks in periods 1 and 2

\begin{tabular}{|c|c|c|c|c|c|}
\hline \multirow[b]{2}{*}{ Item } & \multicolumn{2}{|c|}{ Alfalfa baleage ${ }^{1}$} & \multirow[b]{2}{*}{$\mathrm{SED}^{2}$} & \multirow[b]{2}{*}{$P$-value ${ }^{3}$} & \multirow[b]{2}{*}{ Concentrate $^{4}$} \\
\hline & High NSC & Low NSC & & & \\
\hline \multicolumn{6}{|l|}{ EAA } \\
\hline His & 2.6 & 2.5 & 0.11 & 0.95 & 2.8 \\
\hline Ile & 7.0 & 7.0 & 0.42 & 0.95 & 3.8 \\
\hline Leu & 11.9 & 12.2 & 0.69 & 0.72 & 10.5 \\
\hline Lys & 7.9 & 7.2 & 0.42 & 0.12 & 4.8 \\
\hline Met & 2.3 & 2.4 & 0.12 & 0.60 & 1.6 \\
\hline Phe & 7.3 & 7.4 & 0.80 & 0.42 & 5.3 \\
\hline Thr & 6.7 & 6.5 & 0.28 & 0.64 & 4.2 \\
\hline Val & 7.6 & 7.7 & 0.40 & 0.78 & 4.3 \\
\hline BCAA $^{5}$ & 26.5 & 26.9 & 1.5 & 0.80 & 18.6 \\
\hline Total & 53.2 & 53.0 & 2.5 & 0.91 & 37.3 \\
\hline \multicolumn{6}{|l|}{ NEAA } \\
\hline Ala & 8.2 & 9.0 & 0.64 & 0.22 & 6.6 \\
\hline Asp & 16.6 & 16.1 & 1.1 & 0.65 & 10.6 \\
\hline Glu & 12.1 & 12.0 & 0.64 & 0.90 & 19.6 \\
\hline Gly & 7.5 & 7.8 & 0.36 & 0.50 & 4.8 \\
\hline Pro & 8.6 & 8.4 & 0.38 & 0.61 & 7.8 \\
\hline Ser & 7.0 & 6.9 & 0.30 & 0.77 & 5.6 \\
\hline Tyr & 5.0 & 4.8 & 0.26 & 0.47 & 4.1 \\
\hline Total & 66.5 & 66.6 & 2.9 & 0.99 & 59.0 \\
\hline Total $\mathrm{AA}^{6}$ & 120 & 120 & 5.3 & 0.96 & 96.3 \\
\hline
\end{tabular}

${ }^{1}$ High- and low-NSC alfalfa baleages were analyzed individually for AA in samples collected from d 15 to 18 in each period ( $\mathrm{n}=4$ samples/treatment).

${ }^{2} \mathrm{SED}=$ standard error of the LSM difference.

${ }^{3}$ Two-sample $t$-test for probability of treatment effect (high- vs. low-NSC alfalfa baleage).

${ }^{4}$ Samples of concentrate used for chemical analyses of AA were pooled from d 15 to 21 in each period.

${ }^{5} \mathrm{BCAA}=$ branched-chain $\mathrm{AA}(\mathrm{Ile}+\mathrm{Leu}+\mathrm{Val})$.

${ }^{6}$ Total $\mathrm{AA}=$ total $\mathrm{EAA}+$ total NEAA.

parent mold contamination, which changed the initial preplanned pairing by replacing moldy with nonmoldy bales originally assigned to be fed the following day. Consequently, the difference in NSC concentration between alfalfa baleages fluctuated more than originally expected (Figure 1).

Bales fed during d 14 to 21 of each period $(\mathrm{n}=8$ samples/treatment) were re-cored and reanalyzed for NSC fractions as described above, and concentrate samples collected weekly throughout the experiment were pooled per period by mixing equal amounts of DM. Reducing sugars (sucrose, glucose, and fructose) and the nonreducing sugar pinitol were quantified by HPLC (Waters, Milford, MA) following a 3-min centrifugation at 21,000 $\times g\left(4^{\circ} \mathrm{C}\right)$ using a Bio-Rad Aminex column (HPX-87P, $7.8 \times 300 \mathrm{~mm}$; Bio-Rad, Hercules, $\mathrm{CA}$ ) and detected on a refractive index detector as described by Bigras and Bertrand (2006). Starch in alfalfa and concentrate samples was analyzed according to the procedures described by Bertrand et al. (2007). Briefly, the insoluble residues left after extraction were washed twice with methanol and used for starch quantification as glucose equivalent with the $p$-hydroxybenzoic acid hydrazide method of Blakeney and Mutton (1980) after gelatinization at $100^{\circ} \mathrm{C}$ and digestion for 90 min with amyloglucosidase (A7255, Sigma Chemical Co., St. Louis, MO). In addition, differential solubilities of carbohydrates in 80:20 (vol:vol) ethanol:water were used to partition the neutral detergent soluble carbohydrates of individual alfalfa baleage samples (d 14 to 21 in each period) into organic acids, and mono- and oligosaccharides soluble in aqueous ethanol [i.e., total ethanolsoluble carbohydrates (TESC)] from starch and neutral detergent soluble fiber, which are insoluble (Hall et al., 1999; Hall, 2000). Mono- and oligosaccharides were measured colorimetrically in the ethanol:water extract using the phenol-sulfuric acid method of Dubois et al. (1956) with a sucrose standard, whereas starch was analyzed enzymatically on the ethanol:water insoluble residue following the method of Holm et al. (1986) as modified by Hall (2000). Glucose hydrolyzed from starch was measured using glucose oxidase-peroxidase reagent (Karkalas, 1985). Concentrate samples were analyzed for TESC and starch, and concentration of NSC in feeds was also computed by adding TESC plus starch (Table 1).

Baleage and concentrate samples were also analyzed for analytical DM (method 930.15; AOAC Internation- 
$\rightarrow$-high-NSC $\rightarrow$-low-NSC
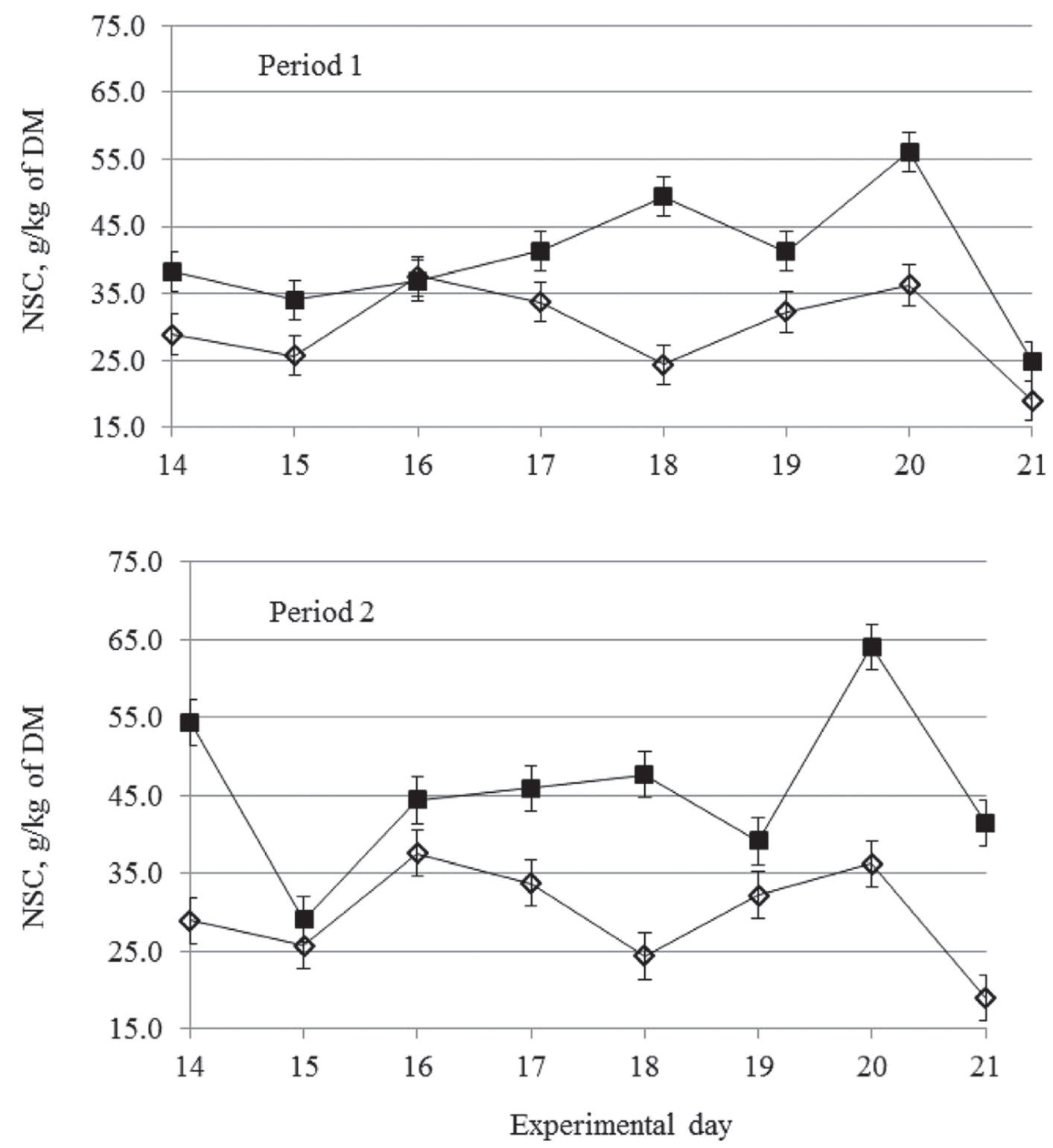

Figure 1. Daily concentrations (mean \pm SED) of NSC (water-soluble carbohydrates + starch) in each pair of alfalfa baleages offered (d 14 to 21) to early lactation Holstein cows during period 1 and period 2.

al, 2006) and ash with a thermogravimetric analyzer (model TGA-601; Leco Corporation, St. Joseph, MI); total N, NDIN, and ADIN using micro-Kjeldahl analysis (Kjeltec 2400 instrument; Foss Analytical, Hillerød, Denmark; method 976.06; AOAC International, 2006); NDF and ADF with the Ankom ${ }^{200}$ fiber analyzer (Ankom Technology, Fairport, NY) using heat-stable

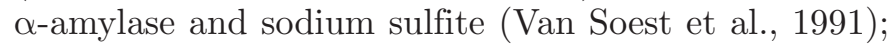
and ether extract with a Soxtec system HT6 apparatus (Tecator, Fisher Scientific, Montreal, Canada). Concentrations of AA in the baleage and concentrate samples were determined by the isotope dilution method of Calder et al. (1999) after a 24-h acid hydrolysis with $6 \mathrm{~N} \mathrm{HCl}$-phenol at $110^{\circ} \mathrm{C}$ (AOAC International, 2000) as described by Borucki Castro et al. (2007). A second acid hydrolysis using performic acid oxidation was performed for the analysis of Met (method 994.12; AOAC International, 2000). A mixture of labeled AA $\left({ }^{13} \mathrm{C}\right.$ and ${ }^{15} \mathrm{~N}$ AA isotope standards; CDN isotopes, PointeClaire, QC, Canada; Cambridge Isotope Laboratories Inc., Andover, MA) was used as an internal standard. Amino acid enrichment was quantified using GC-MS 
(Hewlett-Packard model GC6890-MS5973; Agilent Technologies, Wilmington, DE).

Baleage extracts were prepared by mixing $20 \mathrm{~g}$ of thawed alfalfa samples in $100 \mathrm{~mL}$ of distilled water followed by agitation and then $2 \mathrm{~h}$ of maceration at room temperature with occasional agitation. The $\mathrm{pH}$ of the extracts was measured with a $\mathrm{pH}$ meter (Accumet $\mathrm{pH}$ meter model 815 MP, Fisher Scientific, Fairlawn, NJ) followed by the addition of $100 \mathrm{~mL}$ of a $0.1 \mathrm{M}$ solution of $\mathrm{HCl}$ and an additional $24 \mathrm{~h}$ of maceration at $4^{\circ} \mathrm{C}$ with occasional agitation. The extracts were filtered with Whatman no. 54 filter paper (catalog no. 1454150, Whatman International Ltd., Maidstone, UK) and the filtrates were frozen at $-20^{\circ} \mathrm{C}$ for later analysis of VFA with a GLC instrument (Hewlett-Packard 6890N; Hewlett-Packard Inc., Montreal, QC, Canada) equipped with a flame-ionization detector and a $7683 \mathrm{~B}$ model autosampler as described by Delbecchi et al. (2001). Orts collected from all cows were pooled by cow from d 15 to 21 in each period, stored at $-20^{\circ} \mathrm{C}$, lyophilized, and ground to pass through a 1-mm screen. Samples were then analyzed for analytical DM, ash, total N, $\mathrm{NDF}$, and ADF using the procedures described for the baleages and concentrate.

\section{Ruminal, Omasal, Fecal, and Urine Sampling and Analyses}

Samples of whole ruminal contents (about $200 \mathrm{~g}$ ) were taken from the ventral sac of 8 ruminally cannulated cows at 0700, 0800, 1100, 1400, 1700, and 2000 $\mathrm{h}$ on d 15; 1000, 1300, 1600, and $1900 \mathrm{~h}$ on d 16; and 0900, 1200, 1500, and $1800 \mathrm{~h}$ on d 17 of each period. Ruminal digesta samples were strained through 2 layers of cheesecloth with $\mathrm{pH}$ measurements $(\mathrm{pH} /$ temp meter 199 model No 3D; Fisher Scientific, Pittsburgh, PA) following immediately. Two $10-\mathrm{mL}$ samples were then preserved by addition of $0.2 \mathrm{~mL}$ of $50 \% \mathrm{H}_{2} \mathrm{SO}_{4}$ and stored at $-20^{\circ} \mathrm{C}$ until analysis. Samples were thawed at room temperature, centrifuged $(25,200 \times g, 15 \mathrm{~min}$, $4^{\circ} \mathrm{C}$ ), and supernatants analyzed for $\mathrm{NH}_{3}-\mathrm{N}$ using the indophenol-blue method of Novozamsky et al. (1974) and for VFA with a GLC instrument as previously described.

Spot samples of omasal digesta leaving the rumen were collected through the reticulo-omasal orifice from the 8 ruminally cannulated cows using the omasal sampling technique developed by Huhtanen et al. (1997) and Ahvenjärvi et al. (2000), as adapted by Reynal et al. (2003). The following omasal digesta markers were used: indigestible NDF (Huhtanen et al., 1994) for the large particle phase $(\mathbf{L P}), \mathrm{YbCl}_{3}$ (modified from Siddons et al., 1985) for the small particle phase (SP), and Co-EDTA (Udén et al., 1980) for the fluid phase (FP).
A marker solution containing $\mathrm{YbCl}_{3}, \mathrm{Co}-\mathrm{EDTA}$, and ${ }^{15} \mathrm{NH}_{4} \mathrm{SO}_{4}$ with 10 atom percentage excess ${ }^{15} \mathrm{~N}$ (Isotec, Miamisburg, $\mathrm{OH}$ ) as a microbial marker was prepared as described by Reynal and Broderick (2005). A sample of $500 \mathrm{~mL}$ of omasal digesta (background) was taken from each cow before the beginning of marker infusion to determine the natural abundance of ${ }^{15} \mathrm{~N}$. Cows were then pulse-dosed with $3.0 \mathrm{~L}$ of the same 3-marker solution used during the continuous infusion. The external markers Co-EDTA, $\mathrm{YbCl}_{3}$, and ${ }^{15} \mathrm{NH}_{4} \mathrm{SO}_{4}$ were continuously infused into the rumen from d 11 to $17(154 \mathrm{~h}$ of infusion) using 4 peristaltic pumps (Masterflex L/S model no. 7523-50; Cole-Parmer Instrument Co., Barrington, IL) at an average constant rate of $3.12 \mathrm{~L} / \mathrm{d}$ providing $2.69 \mathrm{~g}$ of $\mathrm{Co}, 3.10 \mathrm{~g}$ of $\mathrm{Yb}$, and $0.25 \mathrm{~g}$ of ${ }^{15} \mathrm{~N} / \mathrm{d}$. Omasal sampling was initiated approximately $87 \mathrm{~h}$ after beginning the marker infusion with samples taken 4 times daily at 3 -h intervals over 3 consecutive days: 1100, 1400, 1700, and $2000 \mathrm{~h}$ on d 15; 1000, 1300, 1600, and $1900 \mathrm{~h}$ on d 16; and 0900, 1200, 1500, and $1800 \mathrm{~h}$ on d 17 of each period. The omasal sampling tube was kept inserted into the reticulo-omasal orifice for the entire collection of omasal digesta, which lasted approximately $7 \mathrm{~h} / \mathrm{d}$. At each of the 4 daily sampling times, a 500-mL spot sample of omasal digesta was collected and split under continuous mechanical agitation into 2 subsamples of 100 and $400 \mathrm{~mL}$. The 4 daily $100-\mathrm{mL}$ subsamples were pooled and stored on ice inside a refrigerator $\left(4^{\circ} \mathrm{C}\right)$ for the duration of the daily omasal digesta collection. These 4 daily $100-\mathrm{mL}$ subsamples were pooled into a single composite of 400 $\mathrm{mL}$ per cow that was transported to the laboratory for bacterial isolation. Therefore, 3 composites of $400 \mathrm{~mL}$ were obtained over the 3 sampling days for each cow in each period. The 4 daily $400-\mathrm{mL}$ subsamples were stored at $-20^{\circ} \mathrm{C}$ and pooled over $3 \mathrm{~d}$ to obtain a single 4.8-L composite from each cow in each period for later separation into the 3 omasal phases (LP, SP, and FP).

The fluid-associated bacteria (FAB) and particleassociated bacteria (PAB) were isolated from the daily 400-mL composites from each cow on each of the 3 sampling days using filtration and differential centrifugation as described previously in detail (Brito et al., 2009). The resulting FAB and PAB pellets were stored at $-20^{\circ} \mathrm{C}$, lyophilized, ground with a mortar and pestle, and finally pooled by cow per period by mixing equal amounts of DM for later analysis. The 4.8-L pooled omasal composites were thawed at room temperature, separated into the 3 omasal phases (LP, SP, and FP) as described by Brito et al. (2009), and stored at $-20^{\circ} \mathrm{C}$ until lyophilized. After lyophilization, these samples were ground through a $1-\mathrm{mm}$ screen (Wiley mill; Arthur H. Thomas) followed by analyses of digesta markers using methods detailed previously 
(Brito et al., 2009). Marker concentrations were used to physically recombine DM from the lyophilized FP, SP, and LP in the correct proportions to reconstitute the omasal true digesta flowing out of the rumen using the triple-marker method of France and Siddons (1986).

Reconstituted omasal true digesta samples were analyzed for analytical DM, ash, total N, NDF, ADF, individual sugars, starch (Holm et al., 1986 as modified by Hall, 2000), TESC, and AA as described earlier. Extracts from omasal true digesta samples were also prepared and analyzed for $\mathrm{NH}_{3}-\mathrm{N}$ as reported by Brito et al. (2009). Samples of FAB, PAB, omasal phases, and background omasal digesta were prepared and analyzed for NAN and ${ }^{15} \mathrm{~N}$ analyses as described in detail elsewhere (Brito et al., 2009). Bacterial samples (PAB and $\mathrm{FAB}$ ) were additionally analyzed for analytical DM (overnight at $105^{\circ} \mathrm{C}$ ) and ash $\left(16 \mathrm{~h}\right.$ at $550^{\circ} \mathrm{C}$ ).

Fecal grab samples were collected from the rectum of the 8 ruminally cannulated cows following the omasal sampling schedule (see above). Approximately $100 \mathrm{~g}$ of fecal sample from each cow was collected at each time point, pooled by cow over the $3 \mathrm{~d}$ to obtain a single composite, and then lyophilized. Dried samples were ground to pass through a 1-mm screen and analyzed for analytical DM, ash, total N, NDF, ADF, starch (Holm et al., 1986 as modified by Hall, 2000), and TESC as previously described. Acid-insoluble ash (Van Keulen and Young, 1977) was used as an external marker to estimate the fecal output of DM (Cochran et al., 1986).

Spot urine samples were collected by stimulation of the pudendal nerve, massaging the area below the vulva from the 8 ruminally cannulated cows following the omasal sampling schedule (see above). After collection, $15 \mathrm{~mL}$ of urine was pipetted into a specimen container containing $60 \mathrm{~mL}$ of $0.072 \mathrm{~N} \mathrm{H}_{2} \mathrm{SO}_{4}$ and stored at $-20^{\circ} \mathrm{C}$ until analyzed (Brito and Broderick, 2006). After thawing at room temperature, urine samples were analyzed for creatinine with a commercial kit (catalog no. 221-50; BioPacific Diagnostic Inc., North Vancouver, BC, Canada), urea $\mathrm{N}$ with a Technicon autoanalyzer (industrial method no. 339-01; Technicon Instruments, Tarrytown, NY), and total $\mathrm{N}$ via micro-Kjeldahl analysis (Kjeltec 2400 instrument; Foss Analytical; method 976.06; AOAC International, 2006). Daily urinary volume and excretion of urea $\mathrm{N}$ and total $\mathrm{N}$ were estimated from urinary creatinine concentration assuming a creatinine excretion rate of $29 \mathrm{mg} / \mathrm{kg}$ of BW (Valadares et al., 1999).

\section{Blood Sampling and Analyses}

Approximately $4 \mathrm{~h}$ after feeding on d 18 of each period, coccygeal blood samples were taken and collected into Vacutainer tubes (Becton Dickinson, Franklin
Lakes, NJ) from all 18 cows. Vacutainer tubes containing sodium heparin were used for AA and urea-N analyses, whereas tubes without anticoagulant were used for NEFA determination. After sampling, tubes were kept on ice and centrifuged $\left(2,000 \times \mathrm{g}, 12 \mathrm{~min}, 4^{\circ} \mathrm{C}\right)$. For analysis of AA, $0.2 \mathrm{~g}$ of an internal standard solution of stable isotope-labeled AA (Martineau et al., 2007) was gravimetrically added to $1.0 \mathrm{~g}$ of plasma before storage at $-80^{\circ} \mathrm{C}$. Plasma concentrations of individual AA were determined by the isotope dilution method using a GC-MS as previously described. The remaining plasma was stored at $-20^{\circ} \mathrm{C}$ for later analysis of plasma ureaN (PUN) with a Technicon autoanalyzer (industrial method no. 339-01; Technicon Instruments) and NEFA with a commercial kit (Wako Pure Chemical Industries Ltd., Osaka, Japan) according to McCutcheon and Bauman (1986).

\section{Animal Performance and Milk Analyses}

Cows were milked twice daily at approximately 0600 and $2000 \mathrm{~h}$, and milk yield was recorded at each milking from all 18 cows. Milk samples from a.m. and p.m. milkings were collected from d 14 (p.m.) to d 21 (a.m.) of each experimental period, preserved in tubes containing 2-bromo-2-nitropropan 1,3 diol, and kept at $4^{\circ} \mathrm{C}$ until shipped for determination of fat, protein, lactose, and MUN by mid-infrared reflectance spectroscopy (Valacta; Sainte-Anne-de-Bellevue, QC, Canada). Concentrations and yields of milk components and MUN were computed as the weighted means from a.m. and p.m. milk yields on each test day. Feed efficiency was computed by dividing mean milk yield by mean DMI over the last $7 \mathrm{~d}$ of each period. Apparent efficiency of utilization of feed $\mathrm{N}$ was calculated by dividing mean milk $\mathrm{N}$ secretion (milk $\mathrm{N}$ concentration $\times$ milk yield) by mean $\mathrm{N}$ intake over the last $7 \mathrm{~d}$ of each period. Body weights were recorded at the same time for 3 consecutive days at the beginning of the experiment and at the end of each period to compute BW change.

\section{Statistical Analyses and Calculations}

Data were analyzed using the MIXED procedure of SAS (version 9.3; SAS institute Inc., Cary, NC) according to a crossover design. The following model was fitted for all variables with no repeated measures over time:

$$
\begin{aligned}
\mathrm{Y}_{\mathrm{ijkl}}= & \mu+\mathrm{S}_{\mathrm{i}}+\mathrm{C}_{\mathrm{j}}(\mathrm{S})_{\mathrm{i}}+\mathrm{T}_{\mathrm{k}}+\mathrm{ST}_{\mathrm{ik}} \\
& +\mathrm{PA}_{\mathrm{l}}+\mathrm{TPA}_{\mathrm{kl}}+\mathrm{E}_{\mathrm{ijk} \mathrm{k}},
\end{aligned}
$$

where $Y_{\mathrm{ijkl}}=$ dependent variable, $\mu=$ overall mean, $\mathrm{S}_{\mathrm{i}}=$ mean effect of the ith crossover sequence group, 
$\mathrm{C}_{\mathrm{j}}(\mathrm{S})_{\mathrm{i}}=$ mean effect of jth cow nested within ith sequence, $\mathrm{T}_{\mathrm{k}}=$ mean effect of kth treatment, $\mathrm{ST}_{\mathrm{ik}}=$ interaction between ith crossover sequence group and kth treatment (same as period effect), $\mathrm{PA}_{1}=$ mean effect lth parity, $\mathrm{TPA}_{\mathrm{kl}}=$ interaction between kth treatment and lth parity, and $\mathrm{E}_{\mathrm{ijkl}}=$ random residual variation. All terms were considered fixed except $\mathrm{C}_{\mathrm{j}}(\mathrm{S})_{\mathrm{i}}$ and $\mathrm{E}_{\mathrm{ijkl}}$, which were considered random. All reported values are least squares means (LSM). Differences between LSM were reported only if the $F$-test for treatment was significant at $P \leq 0.05$. Trends were declared at $0.05<$ $P \leq 0.10$.

The following model was fitted for variables with repeated measures over time using 8 ruminally cannulated cows (ruminal $\mathrm{pH}, \mathrm{NH}_{3}-\mathrm{N}$, and VFA):

$$
\begin{gathered}
\mathrm{Y}_{\mathrm{ijkl}}=\mu+\mathrm{S}_{\mathrm{i}}+\mathrm{C}_{\mathrm{j}}(\mathrm{S})_{\mathrm{i}}+\mathrm{T}_{\mathrm{k}}+\mathrm{ST}_{\mathrm{ik}} \\
+\mathrm{E} 1_{\mathrm{ijk}}+\mathrm{H}_{1}+\mathrm{TH}_{\mathrm{kl}}+\mathrm{E} 2_{\mathrm{ijk} \mathrm{k}},
\end{gathered}
$$

where $\mathrm{Y}_{\mathrm{ijkl}}=$ dependent variable, $\mu=$ overall mean, $\mathrm{S}_{\mathrm{i}}=$ mean effect of the ith crossover sequence group, $\mathrm{C}_{\mathrm{j}}(\mathrm{S})_{\mathrm{i}}=$ mean effect of jth cow nested within ith sequence, $\mathrm{T}_{\mathrm{k}}=$ mean effect of kth treatment, $\mathrm{ST}_{\mathrm{ik}}=$ interaction between ith crossover sequence group and kth treatment (same as period effect), $\mathrm{E} 1_{\mathrm{ijk}}=$ wholeplot random residual variation, $\mathrm{H}_{1}=$ mean effect of lth hour postfeeding analyzed as repeated measures, $\mathrm{TH}_{\mathrm{kl}}$ = interaction between kth treatment and lth hour postfeeding, and $\mathrm{E} 2_{\mathrm{ijkl}}=$ subplot random residual variation. The spatial covariance structure with the lowest Akaike information criterion was retained in the final model. The subject of the repeated measurements was defined as cow (period). All terms were considered fixed, except $\mathrm{C}_{\mathrm{j}}(\mathrm{S})_{\mathrm{i}}, \mathrm{E} 1_{\mathrm{ijk}}$, and $\mathrm{E} 2_{\mathrm{ijk}}$, which were considered random. All reported values are LSM. Differences between LSM were reported only if the $F$-test for treatment was significant at $P \leq 0.05$. Trends were declared at $0.05<P$ $\leq 0.10$. Omasal flow of nutrients as well as ${ }^{15} \mathrm{~N}$ enrichment was calculated according to Brito et al. (2009).

\section{RESULTS}

\section{Alfalfa Nutrient Composition}

Compared with the low-NSC alfalfa baleage, the concentrations of glucose, fructose, total reducing sugars, WSC, TESC, and NSC were all highest $(P<0.001)$ in the high-NSC alfalfa baleage (Table 1). No significant differences were observed for the nutrient composition between high- and low-NSC alfalfa baleages except for the concentrations of $\mathrm{OM}(+13 \mathrm{~g}$ of $\mathrm{OM} / \mathrm{kg}$ of $\mathrm{DM}$; $P<0.01)$, ADIN $(+0.7 \%$ of total $\mathrm{N} ; P=0.04)$, Ca $(+0.70 \mathrm{~g}$ of $\mathrm{Ca} / \mathrm{kg}$ of DM; $P=0.01), \mathrm{P}(-0.28 \mathrm{~g}$ of $\mathrm{P} /$ $\mathrm{kg}$ of DM; $P<0.001)$, and $\mathrm{K}(-3.1 \mathrm{~g}$ of $\mathrm{P} / \mathrm{kg}$ of $\mathrm{DM} ; P$ $<0.001$; Table 2). Concentrations of $\mathrm{CP}(P=0.08)$ and lignin $(P=0.10)$ tended to be reduced in the high-NSC alfalfa baleage (Table 2). Baleage $\mathrm{pH}$ averaged 5.9 and did not differ significantly between treatments. Concentrations of acetic acid $(-31 \% ; P=0.03)$, propionic acid $(-42 \% ; P<0.01)$, and total organic acids $(-28 \% ; P=$ $0.05)$ were all reduced in the high-NSC alfalfa baleage (Table 2). No significant differences in the concentrations of individual AA, total EAA, total NEAA, and total AA (EAA plus NEAA) were observed between alfalfa baleages (Table 3 ).

\section{Ruminal Fermentation, Omasal Flow of Nutrients, Digestibility, and N Balance}

Mean ruminal $\mathrm{pH}$ tended $(P=0.06)$ to be reduced in cows fed the high-NSC diet (Table 4). A significant sampling time $\times$ treatment interaction was observed, with the high-NSC diet showing the lowest ruminal $\mathrm{pH}$ at $0800,1000,1700$, and $2000 \mathrm{~h}$ (Figure 2). Conversely, mean concentration of ruminal $\mathrm{NH}_{3}-\mathrm{N}$ was highest $(P$ $=0.03)$ in cows fed the high-NSC diet (Table 4). A significant sampling time $\times$ treatment interaction was also observed, with the high-NSC diet yielding the highest concentrations of ruminal $\mathrm{NH}_{3}-\mathrm{N}$ at 1100 and $1200 \mathrm{~h}$ (Figure 3). Except for the molar proportion of valerate, which was lowest $(P=0.05)$ in multiparous cows fed the high-NSC diet, no other significant changes in ruminal VFA were observed (Table 4). The molar proportion of propionate and the propionate:acetate + butyrate ratio tended $(P=0.09)$ to be reduced when feeding the high-NSC diet.

Total intake, omasal flow, apparent ruminal digestibility, and OM truly digested in the rumen did not differ significantly between treatments (Table 5). On the other hand, postruminal digestibility of OM was highest $(P<0.01)$ in cows fed the high-NSC diet, leading to the highest $(P<0.04)$ apparent total-tract digestibilities of $\mathrm{OM}$ (Table 5). Although intakes of NDF $(P<0.01$; Table 5$)$ and $\operatorname{ADF}(P=0.03$; data not shown) were both lowest in cows fed the high-NSC diet, omasal flows of NDF (Table 5) and ADF (data not shown) did not differ significantly, averaging, respectively, 4.4 and $2.7 \mathrm{~kg} / \mathrm{d}$ across treatments. Apparent ruminal digestibilities of NDF (Table 5) and ADF (data not shown), expressed as a proportion of NDF or ADF intake, decreased numerically $(-3.8$ percentage units) or tended to decrease $(P=0.09 ;-3.1$ percentage units), respectively, when feeding the high-NSC diet. Conversely, postruminal digestibilities of NDF (Table 5 ) and ADF (data not shown), expressed as a proportion of NDF or ADF intake, tended to increase $(P=$ $0.09 ;+6.0$ percentage units $)$ or increased $(P=0.03$; 
Table 4. Effects of offering alfalfa baleage with different concentrations of NSC supplemented with a cornbased concentrate on the ruminal fermentation profile in ruminally cannulated multiparous Holstein cows during early lactation $(\mathrm{n}=8)$

\begin{tabular}{lcccc}
\hline & \multicolumn{3}{c}{ Diet } & \\
\cline { 2 - 3 } Item & High NSC & Low NSC & SED $^{1}$ & $P$-value \\
\hline $\mathrm{pH}$ & 6.35 & 6.44 & 0.04 & 0.06 \\
$\mathrm{NH}_{3}$-N, mg/dL & 11.8 & 10.4 & 0.65 & 0.03 \\
Total VFA, mM & 109 & 105 & 6.0 & 0.52 \\
VFA, mol/100 mol & & & & \\
Acetate (A) & 70.6 & 69.4 & 0.84 & 0.21 \\
Propionate (P) & 15.5 & 16.5 & 0.46 & 0.09 \\
Butyrate (B) & 9.9 & 9.9 & 0.29 & 0.90 \\
Isobutyrate & 1.25 & 1.41 & 0.27 & 0.58 \\
Valerate & 1.0 & 1.2 & 0.08 & 0.05 \\
Isovalerate & 1.7 & 1.6 & 0.25 & 0.77 \\
A:P ratio & 4.6 & 4.3 & 0.55 & 0.59 \\
P/(A + B) & 0.19 & 0.21 & 0.01 & 0.09 \\
\hline
\end{tabular}

${ }^{1} \mathrm{SED}=$ standard error of the LSM difference.

${ }^{2}$ Probability of treatment effect (high- vs. low-NSC diet); significance was declared at $P \leq 0.05$ and trends at $0.05<P \leq 0.10$.

+6.2 percentage units), respectively, in cows fed the high-NSC diet. Apparent total-tract digestibilities of NDF (mean $=66 \%$ of NDF intake; Table 5 ) and ADF $($ mean $=63 \%$ of ADF intake; data not shown) did not differ significantly between treatments.

Total intake $(P<0.001)$ as well as ruminal $(P \leq 0.01)$ and total-tract $(P \leq 0.01)$ digestibilities of TESC were highest in cows fed the high-NSC diet (Table 5). On the other hand, total intake, omasal flow, and gastrointestinal tract (i.e., rumen, postrumen, and total-tract) digestibilities of starch (measured as glucose equivalent using oxidase-peroxidase; Hall, 2000) and NSC (calculated as TESC plus starch) did not differ significantly between treatments (Table 5). Similarly, omasal flows of maltose, pinitol, WSC, starch (measured as glucose equivalent using $p$-hydroxybenzoic acid hydrazide;

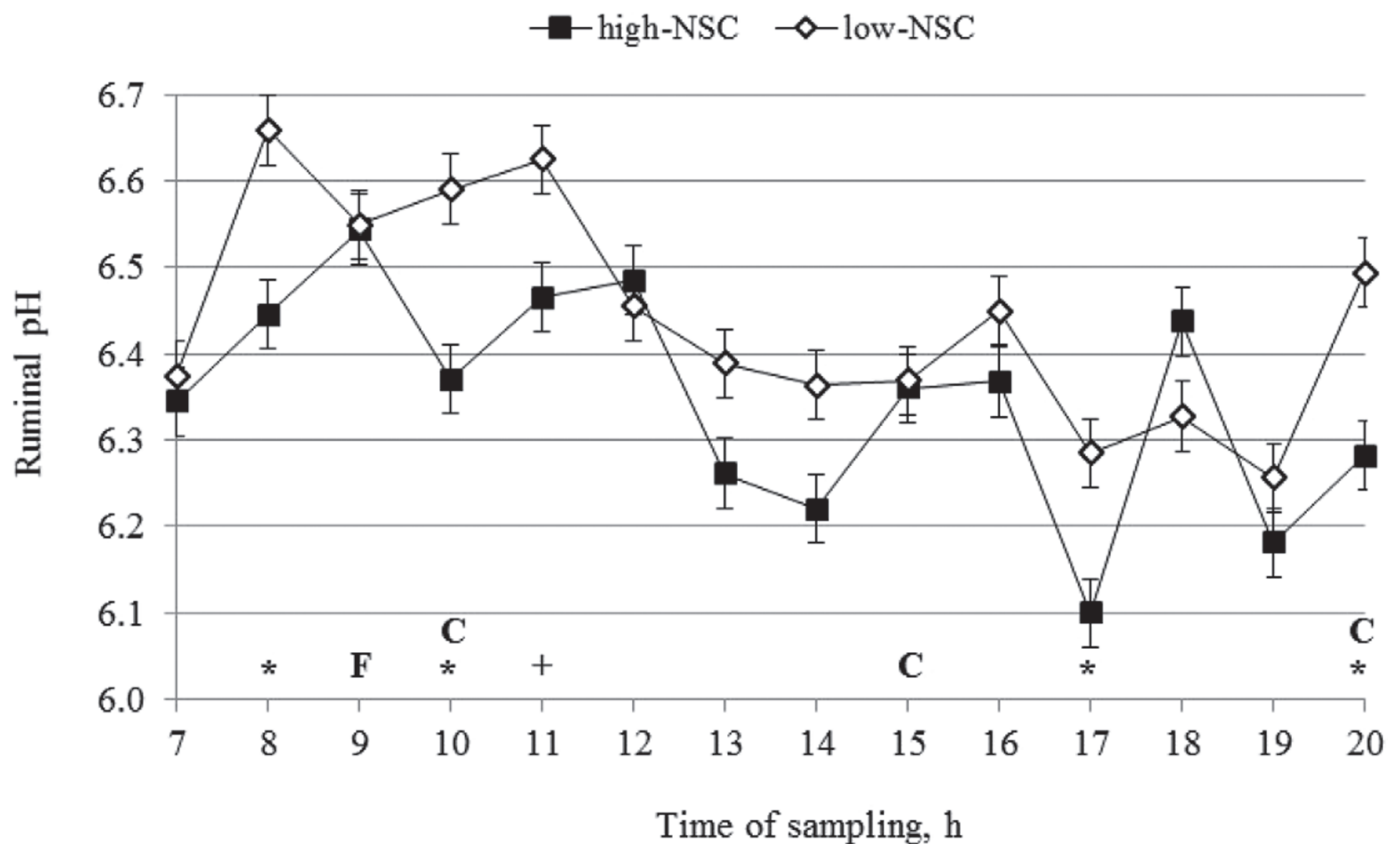

Figure 2. Diurnal variation in ruminal $\mathrm{pH}$ (mean $\pm \mathrm{SED}$ ) in multiparous ruminally cannulated Holstein cows $(\mathrm{n}=8)$ during early lactation offered diets containing alfalfa baleage with different concentrations of NSC. A significant time of sampling $\times$ treatment interaction $(P=$ $0.05)$ was observed and differences $\left(^{*}\right)$ between treatments at each sampling time were found at $0800(P=0.02), 1000(P=0.02), 1700(P=$ $0.04)$, and $2000 \mathrm{~h}(P=0.02)$; a trend $(+)$ was observed at $1100 \mathrm{~h}(P=0.08)$. Cows were fed forage $(\mathrm{F})$ at $0900 \mathrm{~h}$ and a common corn-based concentrate (C) at 1000, 1500, and $2000 \mathrm{~h}$ divided in 3 equal portions. Spot ruminal samples were collected over the course of $3 \mathrm{~d}$ (d 15 to 18 ). 


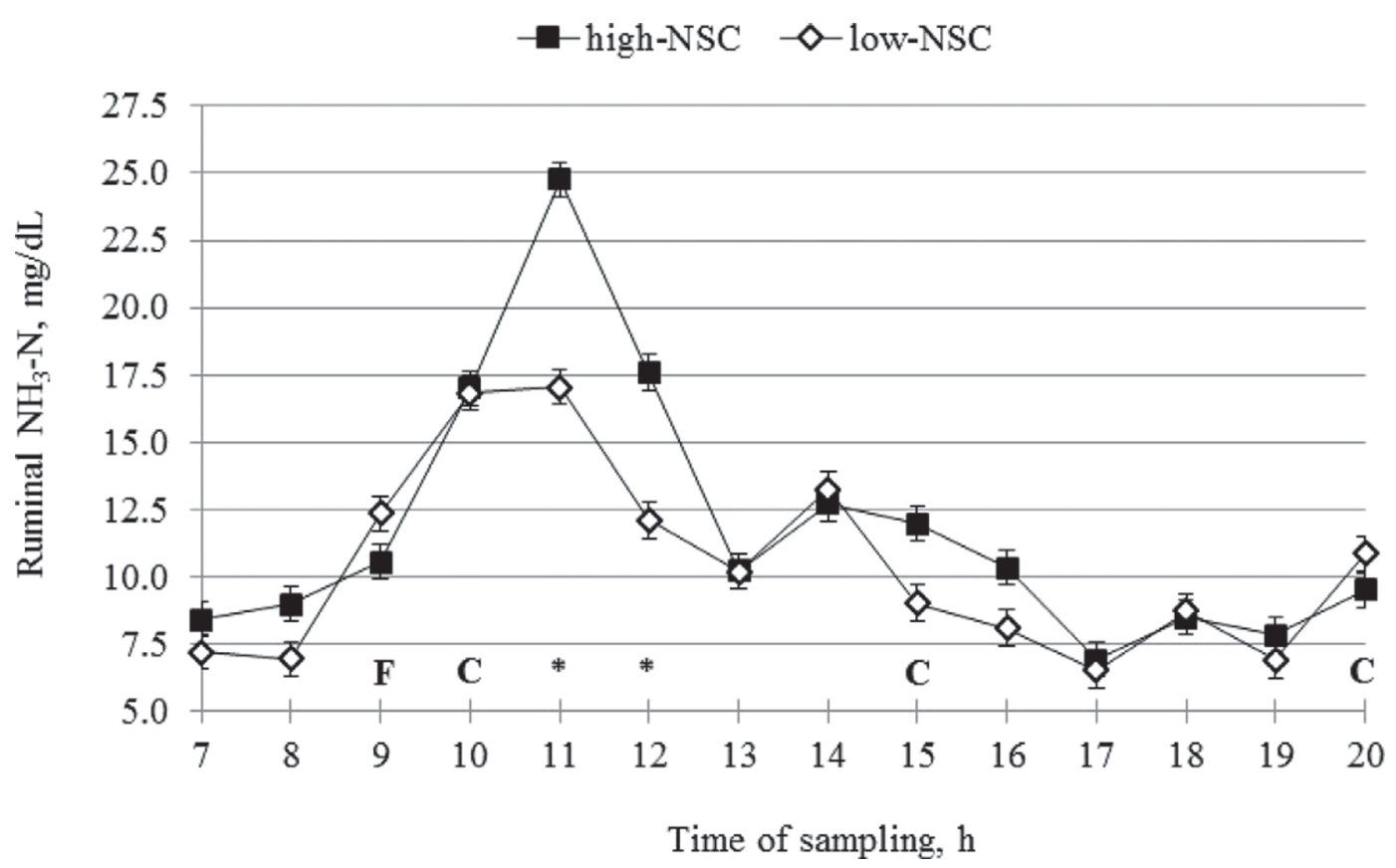

Figure 3. Diurnal variation in the concentration of ruminal $\mathrm{NH}_{3}-\mathrm{N}$ (mean $\pm \mathrm{SED}$ ) in ruminally cannulated multiparous Holstein cows ( $\mathrm{n}=$ 8) during early lactation offered diets containing alfalfa baleage with different concentrations of NSC. A significant time of sampling $\times$ treatment interaction $(P=0.02)$ was observed and differences $\left(^{*}\right)$ between treatments at each sampling time were found at $1100(P<0.001)$ and $1200 \mathrm{~h}(P$ $<0.01)$. Cows were fed forage (F) at $0900 \mathrm{~h}$ and a common corn-based concentrate (C) at 1000, 1500, and $2000 \mathrm{~h}$ divided into 3 equal portions. Spot ruminal samples were collected over the course of $3 \mathrm{~d}$ (d 15 to 18).

Bertrand et al., 2007), NSC (calculated as WSC plus starch) were similar between the 2 experimental diets (Table 5).

Total intake of $\mathrm{N}(P=0.03)$ as well as apparent ruminal digestibility of $\mathrm{N}(P=0.05)$ were reduced when feeding the high-NSC diet (Table 6). However, $\mathrm{N}$ truly digested in the rumen did not $\operatorname{differ}(P=$ 0.93 ) between the 2 experimental diets. Postruminal digestibility of $\mathrm{N}(+8.5$ percentage units; $P=0.01)$ was highest when feeding the high-NSC diet. Conversely, apparent total-tract digestibility of $\mathrm{N}$ did not differ significantly between treatments (Table 6). Omasal flows of all nitrogenous fractions, including total bacterial NAN and individual AA, did not differ significantly between treatments (Tables 6 and 7). However, omasal flows of $\mathrm{N}$ and NAN, as a proportion of $\mathrm{N}$ intake, either increased $(P=0.05)$ or tended to increase $(P=0.06)$ in cows fed the high-NSC diet (Table 6). Efficiency of bacterial protein synthesis did not differ significantly between treatments when expressed as grams of bacterial NAN per kilogram of OM truly digested in the rumen $($ mean $=24.1 \mathrm{~g} / \mathrm{kg})$ but it was highest $(P=$ $0.05)$ with feeding the high-NSC diet when expressed as grams of bacterial NAN per gram of RDP-N (Table 6).

Apparently retained $\mathrm{N}$ did not differ significantly between treatments but it ranged from a positive $(+6.2$ $\mathrm{g} / \mathrm{d}$; high-NSC diet) to a negative $(-9.2 \mathrm{~g} / \mathrm{d}$; low-NSC diet) balance (Table 8). Similarly, apparently retained $\mathrm{N}$ did not differ significantly between treatments when expressed as a proportion of $\mathrm{N}$ intake. With the exception of urinary urea $\mathrm{N}$ expressed as a proportion of manure $\mathrm{N}$, which was highest $(P<0.01)$ in cows fed the high-NSC diet, no other significant changes in fecal $\mathrm{N}$, urinary $\mathrm{N}$, and urinary urea $\mathrm{N}$ were observed between the 2 experimental diets (Table 8 ).

\section{Animal Performance and Plasma Concentrations of $A A$}

Although forage DMI was lowest $(P=0.05)$ in cows fed the high-NSC diet, concentrate DMI did not differ $(P=0.88)$ between diets, thus resulting in no treatment effect $(P=0.14)$ on total DMI (i.e., forage plus concentrate DMI) when all 18 cows were included in the data set (Table 9). Forage intakes of OM $(-0.5 \mathrm{~kg} / \mathrm{d}$; $P=0.10), \mathrm{N}(-31 \mathrm{~g} / \mathrm{d} ; P<0.01), \mathrm{NDF}(-0.4 \mathrm{~kg} / \mathrm{d}$; $P=0.03)$, and $\operatorname{ADF}(-0.4 \mathrm{~kg} / \mathrm{d} ; P=0.03)$ were also lowest with the high-NSC diet when all 18 cows were included in the data set (Table 9). In contrast, intake of forage NSC was highest $(+140 \mathrm{~g} / \mathrm{d} ; P<0.001)$ when feeding the high-NSC diet (Table 9). Due to the lack of differences in the intake of concentrate NSC (mean $=6.4 \mathrm{~kg} / \mathrm{d}), \mathrm{OM}($ mean $=9.4 \mathrm{~kg} / \mathrm{d}), \mathrm{N}($ mean $=204$ $\mathrm{g} / \mathrm{d}), \operatorname{NDF}($ mean $=1.0 \mathrm{~kg} / \mathrm{d})$, and $\operatorname{ADF}($ mean $=0.4$ 
Table 5. Effects of offering alfalfa baleage with different concentrations of NSC supplemented with a cornbased concentrate on intakes, omasal flows, and gastrointestinal digestibilities of OM, NDF, and NSC fractions in ruminally cannulated multiparous Holstein cows during early lactation $(\mathrm{n}=8)$

\begin{tabular}{|c|c|c|c|c|}
\hline \multirow[b]{2}{*}{ Item } & \multicolumn{2}{|c|}{ Diet } & \multirow[b]{2}{*}{$\mathrm{SED}^{1}$} & \multirow[b]{2}{*}{$P$-value ${ }^{2}$} \\
\hline & High NSC & Low NSC & & \\
\hline OM intake, $\mathrm{kg} / \mathrm{d}$ & 21.6 & 21.7 & 0.26 & 0.76 \\
\hline OM omasal flow, $\mathrm{kg} / \mathrm{d}$ & 11.0 & 10.9 & 0.30 & 0.70 \\
\hline OM apparently digested in the rumen, $\%$ of intake & 49.3 & 50.1 & 1.3 & 0.54 \\
\hline OM truly digested in the rumen, $\%$ of intake & 68.7 & 68.6 & 1.1 & 0.97 \\
\hline OM apparently digested postruminally, $\%$ of intake & 25.4 & 20.1 & 1.0 & $<0.01$ \\
\hline OM apparently digested in the total tract, $\%$ of intake & 74.7 & 70.2 & 1.7 & 0.04 \\
\hline NDF intake, kg/d & 6.61 & 7.05 & 0.10 & $<0.01$ \\
\hline NDF omasal flow, $\mathrm{kg} / \mathrm{d}$ & 4.37 & 4.41 & 0.18 & 0.82 \\
\hline NDF apparently digested in the rumen, $\%$ of intake & 33.9 & 37.1 & 2.16 & 0.19 \\
\hline NDF apparently digested postruminally, $\%$ of intake & 33.2 & 26.9 & 3.03 & 0.09 \\
\hline NDF apparently digested in the total tract, $\%$ of intake & 67.1 & 64.0 & 2.15 & 0.21 \\
\hline TESC $^{3}$ intake, $\mathrm{g} / \mathrm{d}$ & 799 & 680 & 12.4 & $<0.001$ \\
\hline TESC omasal flow, $\mathrm{g} / \mathrm{d}$ & 79.8 & 87.4 & 4.1 & 0.11 \\
\hline TESC apparently digested in the rumen, $\%$ of intake & 89.8 & 87.2 & 0.71 & 0.01 \\
\hline TESC apparently digested postruminally, $\%$ of intake & 1.4 & 0.13 & 0.81 & 0.18 \\
\hline TESC apparently digested in the total tract, $\%$ of intake & 91.1 & 87.4 & 0.81 & $<0.01$ \\
\hline $\mathrm{Starch}^{4}$ intake, $\mathrm{kg} / \mathrm{d}$ & 5.7 & 5.7 & 0.08 & 0.96 \\
\hline Starch omasal flow, $\mathrm{kg} / \mathrm{d}$ & 1.0 & 0.93 & 0.11 & 0.51 \\
\hline Starch apparently digested in the rumen, $\%$ of intake & 82.5 & 83.8 & 1.9 & 0.52 \\
\hline Starch apparently digested postruminally, \% of intake & 6.2 & 4.0 & 2.3 & 0.38 \\
\hline Starch apparently digested in the total tract, $\%$ of intake & 88.7 & 87.8 & 1.8 & 0.67 \\
\hline $\mathrm{NSC}^{5}$ intake, $\mathrm{kg} / \mathrm{d}$ & 6.5 & 6.4 & 0.09 & 0.25 \\
\hline NSC omasal flow, $\mathrm{kg} / \mathrm{d}$ & 1.1 & 1.0 & 0.11 & 0.55 \\
\hline NSC apparently digested in the rumen, $\%$ of intake & 83.4 & 84.2 & 1.70 & 0.65 \\
\hline NSC apparently digested postruminally, $\%$ of intake & 10.8 & 8.1 & 2.3 & 0.29 \\
\hline NSC apparently digested in the total tract, $\%$ of intake & 90.0 & 87.8 & 1.67 & 0.51 \\
\hline Flow at the omasal canal & & & & \\
\hline Maltose, $\mathrm{g} / \mathrm{d}$ & 37.4 & 37.1 & 1.6 & 0.86 \\
\hline Pinitol, g/d & 13.7 & 11.5 & 2.0 & 0.32 \\
\hline $\mathrm{WSC}^{6}{ }^{6} \mathrm{~g} / \mathrm{d}$ & 51.1 & 48.6 & 3.5 & 0.51 \\
\hline Starch,${ }^{7} \mathrm{~kg} / \mathrm{d}$ & 1.3 & 1.2 & 0.13 & 0.37 \\
\hline $\mathrm{NSC},{ }^{8} \mathrm{~kg} / \mathrm{d}$ & 1.4 & 1.3 & 0.13 & 0.37 \\
\hline
\end{tabular}

${ }^{1} \mathrm{SED}=$ standard error of the LSM difference.

${ }^{2}$ Probability of treatment (high- vs. low-NSC diet) effect; significance was declared at $P \leq 0.05$ and trends at $0.05<P \leq 0.10$.

${ }^{3} \mathrm{TESC}=$ total ethanol-soluble carbohydrates.

${ }^{4}$ Analyzed as glucose equivalent using oxidase-peroxidase after sample extraction with ethanol (Hall, 2000).

${ }^{5} \mathrm{NSC}=$ TESC + starch (analyzed as reported by Hall, 2000).

${ }^{6} \mathrm{WSC}$ (water-soluble carbohydrates) = maltose + pinitol.

${ }^{7}$ Analyzed as glucose equivalent using $p$-hydroxybenzoic acid hydrazide after sample extraction with methanol (Bertrand et al., 2007).

${ }^{8} \mathrm{NSC}=\mathrm{WSC}+$ starch (analyzed as reported by Bertrand et al., 2007).

$\mathrm{kg} / \mathrm{d}$ ), total nutrient intake either did not change (i.e., NSC and $\mathrm{OM}$ ) or it was significantly decreased (i.e., N, $\mathrm{NDF}, \mathrm{ADF}$ ) in cows fed the high-NSC diet.

Although milk yield did and feed efficiency expressed as ratios of milk yield:DMI, $4 \%$ FCM:DMI, and ECM:DMI did not differ significantly between treatments, both $4 \%$ FCM $(P=0.05)$ and $\operatorname{ECM}(P=0.06)$ decreased when feeding the high-NSC diet (Table 9). Concentration $(-0.02$ percentage units; $P<0.001)$ and yield $(-70 \mathrm{~g} / \mathrm{d} ; P=0.01)$ of milk fat were lowest in cows fed the high-NSC diet (Table 9). Concentration of milk protein tended $(P=0.08)$ to decrease with feeding the high-NSC diet but no difference $(P=0.23)$ was observed for milk protein yield between the 2 treatments (Table 9). Similarly, concentration and yield of milk lactose did not differ significantly when comparing diets containing alfalfa baleage with contrasting NSC levels. Concentration of MUN was lowest $(P<0.01)$ in cows fed the high-NSC diet (Table 9). As expected, concentration of PUN followed that of MUN and tended $(P$ $=0.08)$ to be reduced with feeding the high-NSC diet (Table 9). Milk $\mathrm{N}$ efficiency, expressed as ratio of milk $\mathrm{N}$ to $\mathrm{N}$ intake, was not affected by dietary concentration of NSC (Tables 8 and 9).

No significant effect of dietary NSC was observed for the plasma concentrations of individual EAA, 
Table 6. Effects of offering alfalfa baleage with different concentrations of NSC supplemented with a cornbased concentrate on intake, gastrointestinal digestibilities, and omasal flows of nitrogenous fractions in ruminally cannulated multiparous Holstein cows during early lactation $(\mathrm{n}=8)$

\begin{tabular}{|c|c|c|c|c|}
\hline \multirow[b]{2}{*}{ Item } & \multicolumn{2}{|c|}{ Diet } & \multirow[b]{2}{*}{$\mathrm{SED}^{1}$} & \multirow[b]{2}{*}{$P$-value ${ }^{2}$} \\
\hline & High NSC & Low NSC & & \\
\hline $\mathrm{N}$ intake, $\mathrm{g} / \mathrm{d}$ & 558 & 578 & 7.2 & 0.03 \\
\hline $\mathrm{N}$ apparently digested in the rumen, $\%$ of intake & 16.6 & 20.3 & 1.5 & 0.05 \\
\hline $\mathrm{N}$ truly digested in the rumen, $\%$ of intake & 81.1 & 81.2 & 1.15 & 0.93 \\
\hline $\mathrm{N}$ apparently digested postruminally, $\%$ of intake & 53.7 & 45.2 & 2.4 & 0.01 \\
\hline $\mathrm{N}$ apparently digested in the total tract, $\%$ of intake & 70.3 & 65.5 & 3.2 & 0.18 \\
\hline \multicolumn{5}{|l|}{ Flow at the omasal canal } \\
\hline $\mathrm{N}, \mathrm{g} / \mathrm{d}$ & 463 & 459 & 11.3 & 0.44 \\
\hline $\mathrm{N}, \%$ of $\mathrm{N}$ intake & 83.4 & 79.7 & 1.5 & 0.05 \\
\hline $\mathrm{NH}_{3}-\mathrm{N}, \mathrm{g} / \mathrm{d}$ & 5.2 & 5.6 & 0.93 & 0.69 \\
\hline NAN, g/d & 457 & 454 & 11.8 & 0.76 \\
\hline NAN, $\%$ of $\mathrm{N}$ intake & 82.4 & 78.7 & 1.6 & 0.06 \\
\hline Total bacterial NAN, $\mathrm{g} / \mathrm{d}$ & 357 & 351 & 11.8 & 0.61 \\
\hline $\mathrm{FAB}^{3} \mathrm{NAN}, \mathrm{g} / \mathrm{d}$ & 121 & 125 & 5.4 & 0.48 \\
\hline $\mathrm{PAB}^{4} \mathrm{NAN}, \mathrm{g} / \mathrm{d}$ & 236 & 225 & 9.5 & 0.32 \\
\hline NANBN, ${ }^{5} \mathrm{~g} / \mathrm{d}$ & 100 & 103 & 5.5 & 0.66 \\
\hline RDP supply, g/d & 2,827 & 2,934 & 68.7 & 0.17 \\
\hline $\mathrm{g}$ of total bacterial NAN $/ \mathrm{kg}$ of OMTDR ${ }^{6}$ & 24.6 & 23.6 & 0.90 & 0.30 \\
\hline $\mathrm{g}$ of total bacterial NAN/g of RDP-N ${ }^{7}$ & 0.80 & 0.75 & 0.02 & 0.05 \\
\hline \multicolumn{5}{|l|}{${ }^{1} \mathrm{SED}=$ standard error of the LSM difference. } \\
\hline $\begin{array}{l}{ }^{2} \text { Probability of treatment (high- vs. low-NSC diet) eff } \\
0.05<P \leq 0.10 . \\
{ }^{3} \mathrm{FAB}=\text { fluid-associated bacteria. } \\
{ }^{4} \mathrm{PAB}=\text { particle-associated bacteria. } \\
{ }^{5} \mathrm{NANBN}=\text { non- } \mathrm{NH}_{3} \text { nonbacterial } \mathrm{N} . \\
{ }^{6} \mathrm{OMTDR}=\mathrm{OM} \text { truly digested in the rumen. } \\
{ }^{7} \mathrm{RDP}-\mathrm{N}=\mathrm{RDP} \text { supply } \div 6.25 .\end{array}$ & significance & s declared a & $P \leq 0.05$ & ad trends \\
\hline
\end{tabular}

branched-chain AA, or total EAA (Table 10). Except for the plasma concentrations of Asp $(P<0.001)$ and Cys $(P=0.05)$, both of which increased in cows fed the high-NSC diet, no other significant changes in the plasma concentrations of individual NEAA or total NEAA were observed (Table 10).

\section{DISCUSSION}

As reported in the Materials and Methods section, the NSC concentration of the p.m.-cut alfalfa baleage was not consistently higher than that of the a.m.-cut alfalfa baleage, in contrast to previous observations (Brito et al., 2008). In fact, the p.m.-cut alfalfa baleage/high-NSC alfalfa baleage was fed in $50 \%$ of the feeding events during the 2 sampling weeks. Although some studies (Fisher et al., 2002; Burns et al., 2005) showed that the concentrations of structural carbohydrates (i.e., NDF and ADF) significantly decreased in p.m.- versus a.m.-cut alfalfa hay due to a dilution effect caused by increased NSC in plant tissues, other studies showed no significant differences in structural carbohydrates between alfalfa hay (Yari et al., 2012a, 2014) or switchgrass (Panicum virgatum L.) and gamagrass (Tripsacum dactyloides L.) baleages cut at p.m. versus a.m. (Huntington and Burns, 2007). In addition, diurnal cutting management did not affect in situ ruminal degradation kinetics of $\mathrm{OM}, \mathrm{CP}, \mathrm{NDF}$, and NFC in alfalfa hay (Yari et al., 2012a,b, 2014), or the rate of decrease in NSC concentration of fresh alfalfa during wilting (Morin et al., 2012). On the other hand, p.m. cutting tended to increase (Yari et al., 2012a) or significantly increased (Yari et al., 2014) leaf content and leaf:stem ratio in alfalfa hay, but these improvements in botanical traits did not result in increased milk production, DMI, or eating and rumination time per unit of DMI (i.e., $\mathrm{min} / \mathrm{kg}$ of DMI) in early-lactation cows fed high-concentrate diets (Yari et al., 2014). Therefore, the lack of a consistent effect of p.m. cutting to significantly change the nutrient composition of forages, particularly the structural carbohydrates fraction, but to consistently increase the NSC concentration in different plant species across different modes of conservation (e.g., hay, baleage, and silage) validates our approach to compare current data with forage composition and animal performance data originated from diurnal cutting management experiments reported in the literature.

The NSC concentration in the high-NSC alfalfa baleage calculated using 2 different analytical methods was 
Table 7. Effects of offering alfalfa baleage with different concentrations of NSC supplemented with a cornbased concentrate on omasal flows of individual and total AA in multiparous Holstein cows during early lactation $(\mathrm{n}=8)$

\begin{tabular}{|c|c|c|c|c|}
\hline \multirow[b]{2}{*}{ Item } & \multicolumn{2}{|c|}{ Diet } & \multirow[b]{2}{*}{$\mathrm{SED}^{1}$} & \multirow[b]{2}{*}{$P$-value ${ }^{2}$} \\
\hline & High NSC & Low NSC & & \\
\hline \multicolumn{5}{|l|}{ EAA } \\
\hline His, g/d & 47.3 & 46.2 & 1.4 & 0.46 \\
\hline Ile, $\mathrm{g} / \mathrm{d}$ & 132 & 128 & 3.2 & 0.25 \\
\hline Leu, g/d & 218 & 212 & 6.7 & 0.41 \\
\hline Lys, g/d & 133 & 127 & 5.2 & 0.31 \\
\hline Met, $\mathrm{g} / \mathrm{d}$ & 68.1 & 66.9 & 2.3 & 0.63 \\
\hline Lys:Met ratio & 2.0 & 1.9 & 0.04 & 0.21 \\
\hline Phe, g/d & 137 & 134 & 4.2 & 0.58 \\
\hline Thr, g/d & 138 & 135 & 4.1 & 0.46 \\
\hline Val, g/d & 128 & 125 & 2.8 & 0.33 \\
\hline $\mathrm{BCAA}^{3} \mathrm{~g} / \mathrm{d}$ & 478 & 465 & 11.8 & 0.31 \\
\hline Total, g/d & 1,002 & 975 & 28.2 & 0.38 \\
\hline \multicolumn{5}{|l|}{ NEAA } \\
\hline Ala, g/d & 164 & 161 & 5.0 & 0.50 \\
\hline Asp, $\mathrm{g} / \mathrm{d}$ & 297 & 283 & 10.1 & 0.22 \\
\hline Glu, g/d & 309 & 297 & 8.4 & 0.21 \\
\hline Gly, g/d & 142 & 140 & 3.8 & 0.63 \\
\hline Pro, g/d & 121 & 116 & 4.0 & 0.33 \\
\hline Ser, $\mathrm{g} / \mathrm{d}$ & 129 & 125 & 4.2 & 0.44 \\
\hline Tyr, g/d & 118 & 115 & 3.3 & 0.48 \\
\hline Total, $\mathrm{g} / \mathrm{d}$ & 1,281 & 1.239 & 38.9 & 0.32 \\
\hline Total AA, ${ }^{4} \mathrm{~g} / \mathrm{d}$ & 2,283 & 2,214 & 66.8 & 0.34 \\
\hline
\end{tabular}

${ }^{1} \mathrm{SED}=$ standard error of the LSM difference.

${ }^{2}$ Probability of treatment (high- vs. low-NSC diet) effect; significance was declared at $P \leq 0.05$ and trends at $0.05<P \leq 0.10$

${ }^{3} \mathrm{BCAA}=$ branched-chain $\mathrm{AA}(\mathrm{Ile}+\mathrm{Leu}+\mathrm{Val})$.

${ }^{4}$ Total $\mathrm{AA}=$ total EAA + total NEAA

similar and averaged $43 \mathrm{~g} / \mathrm{kg}$ of DM (WSC + starch) and $45.6 \mathrm{~g} / \mathrm{kg}$ of DM (TESC + starch). The NSC concentration in the high-NSC alfalfa baleage averaged 128 g of NSC/kg of DM (Brito et al., 2008), thus resulting in a range of 43 (current study) to $128 \mathrm{~g}$ of $\mathrm{NSC} / \mathrm{kg}$ of DM (Brito et al., 2008), which is in line with the

Table 8. Effects of offering alfalfa baleage with different concentrations of NSC supplemented with a cornbased concentrate on urinary volume and $\mathrm{N}$ retention and excretion in ruminally cannulated multiparous Holstein cows during early lactation $(\mathrm{n}=8)$

\begin{tabular}{lccrr}
\hline & \multicolumn{2}{c}{ Diet } & & \\
\cline { 2 - 3 } Item & High NSC & Low NSC & SED $^{1}$ & $P_{\text {-value }}{ }^{2}$ \\
\hline Urine, L/d & 35.0 & 38.1 & 2.2 & 0.21 \\
N intake, g/d & 558 & 578 & 7.2 & 0.03 \\
Milk N secretion, g/d & 151 & 154 & 4.5 & 0.47 \\
Urinary N excretion, g/d & 236 & 232 & 10.1 & 0.74 \\
Fecal N excretion, g/d & 165 & 200 & 19.3 & 0.12 \\
Apparently retained N, g/d & 6.2 & -9.4 & 21.6 & 0.50 \\
Milk N secretion, \% of N intake & 27.1 & 26.9 & 0.55 & 0.67 \\
Urinary N excretion, \% of N intake & 42.1 & 40.7 & 2.2 & 0.55 \\
Fecal N excretion, \% of N intake & 29.7 & 34.5 & 3.2 & 0.18 \\
Apparently retained N, \% of N intake & 1.0 & -2.1 & 4.0 & 0.46 \\
Urinary urea N excretion, g/d & 176 & 169 & 9.1 & 0.45 \\
Urinary urea N excretion, \% of urinary N & 74.0 & 72.2 & 2.4 & 0.49 \\
Urinary urea N excretion, \% of manure N & 43.8 & 39.4 & 0.91 & $<0.01$ \\
Urinary urea N excretion, \% of N intake & 31.5 & 29.6 & 1.8 & 0.35 \\
\hline
\end{tabular}

${ }^{1} \mathrm{SED}=$ standard error of the LSM difference.

${ }^{2}$ Probability of treatment (high- vs. low-NSC diet) effect; significance was declared at $P \leq 0.05$ and trends at $0.05<P<0.10$

${ }^{3}$ Apparently retained $\mathrm{N}=\mathrm{N}$ intake $-($ milk $\mathrm{N}+$ fecal $\mathrm{N}+$ urinary $\mathrm{N})$. 
Table 9. Effects of offering alfalfa baleage with different concentrations of NSC supplemented with a cornbased concentrate on nutrient intake, milk yield and composition, plasma metabolites, and BW gain in Holstein cows during early lactation $(\mathrm{n}=10$ multiparous and 8 primiparous cows $)$

\begin{tabular}{|c|c|c|c|c|}
\hline \multirow[b]{2}{*}{ Item } & \multicolumn{2}{|c|}{ Diet } & \multirow[b]{2}{*}{$\mathrm{SED}^{1}$} & \multirow[b]{2}{*}{$P$-value } \\
\hline & High NSC & Low NSC & & \\
\hline Forage DMI, $\mathrm{kg} / \mathrm{d}$ & 11.2 & 11.9 & 0.33 & 0.05 \\
\hline Concentrate DMI, kg/d & 10.1 & 10.1 & 0.15 & 0.88 \\
\hline Total DMI, kg/d & 21.3 & 22.0 & 0.46 & 0.14 \\
\hline Forage $\mathrm{NSC}^{3}$ intake, $\mathrm{kg} / \mathrm{d}$ & 0.48 & 0.34 & 0.01 & $<0.001$ \\
\hline Concentrate NSC intake, $\mathrm{kg} / \mathrm{d}$ & 6.4 & 6.4 & 0.09 & 0.96 \\
\hline Total NSC intake, $\mathrm{kg} / \mathrm{d}$ & 6.8 & 6.7 & 0.10 & 0.20 \\
\hline Forage OM intake, $\mathrm{kg} / \mathrm{d}$ & 10.1 & 10.6 & 0.30 & 0.10 \\
\hline Concentrate OM intake, $\mathrm{kg} / \mathrm{d}$ & 9.4 & 9.4 & 0.13 & 0.99 \\
\hline Total OM intake, kg/d & 19.5 & 20.0 & 0.41 & 0.22 \\
\hline Forage NDF intake, $\mathrm{kg} / \mathrm{d}$ & 4.8 & 5.2 & 0.15 & 0.03 \\
\hline Concentrate NDF intake, kg/d & 1.0 & 1.0 & 0.01 & 0.86 \\
\hline Total NDF intake, $\mathrm{kg} / \mathrm{d}$ & 5.8 & 6.2 & 0.16 & 0.03 \\
\hline Forage ADF intake, $\mathrm{kg} / \mathrm{d}$ & 4.3 & 4.7 & 0.13 & 0.03 \\
\hline Concentrate ADF intake, kg/d & 0.42 & 0.42 & 0.01 & 0.54 \\
\hline Total ADF intake, $\mathrm{kg} / \mathrm{d}$ & 4.8 & 5.1 & 0.13 & 0.03 \\
\hline Forage $\mathrm{N}$ intake, kg/d & 298 & 329 & 8.8 & $<0.01$ \\
\hline Concentrate $\mathrm{N}$ intake, $\mathrm{kg} / \mathrm{d}$ & 205 & 202 & 5.0 & 0.59 \\
\hline Total $\mathrm{N}$ intake, kg/d & 502 & 529 & 11.9 & 0.04 \\
\hline Milk yield, $\mathrm{kg} / \mathrm{d}$ & 29.7 & 30.0 & 0.53 & 0.58 \\
\hline $4 \% \mathrm{FCM}^{4}, \mathrm{~kg} / \mathrm{d}$ & 27.0 & 28.2 & 0.55 & 0.05 \\
\hline $\mathrm{ECM},{ }^{5} \mathrm{~kg} / \mathrm{d}$ & 28.6 & 29.8 & 0.60 & 0.06 \\
\hline Milk yield:total DMI & 1.4 & 1.4 & 0.03 & 0.28 \\
\hline 4\% FCM:total DMI & 1.3 & 1.3 & 0.03 & 0.73 \\
\hline ECM:total DMI & 1.4 & 1.4 & 0.03 & 0.75 \\
\hline Milk fat, \% & 3.4 & 3.6 & 0.04 & $<0.001$ \\
\hline Milk fat, $\mathrm{kg} / \mathrm{d}$ & 1.0 & 1.1 & 0.02 & 0.01 \\
\hline Milk protein, \% & 2.7 & 2.8 & 0.03 & 0.08 \\
\hline Milk protein, $\mathrm{kg} / \mathrm{d}$ & 0.81 & 0.83 & 0.02 & 0.23 \\
\hline Milk lactose, $\%$ & 4.6 & 4.6 & 0.02 & 0.13 \\
\hline Milk lactose, $\mathrm{kg} / \mathrm{d}$ & 1.4 & 1.4 & 0.03 & 0.39 \\
\hline MUN, mg/dL & 10.8 & 11.8 & 0.26 & $<0.01$ \\
\hline Plasma urea $\mathrm{N}, \mathrm{mg} / \mathrm{dL}$ & 9.6 & 10.3 & 0.42 & 0.08 \\
\hline Milk $\mathrm{N}, \%$ of $\mathrm{N}$ intake & 25.7 & 24.9 & 0.69 & 0.29 \\
\hline Plasma NEFA, mEq/L & 195 & 217 & 22.3 & 0.34 \\
\hline BW gain, $\mathrm{kg} / \mathrm{d}$ & 0.28 & 0.38 & 0.21 & 0.62 \\
\hline
\end{tabular}

${ }^{1} \mathrm{SED}=$ standard error of the LSM difference.

${ }^{2}$ Probability of treatment (high- vs. low-NSC diet) effect; significance was declared at $P \leq 0.05$ and trends at $0.05<P \leq 0.10$

${ }^{3} \mathrm{NSC}=\mathrm{WSC}+$ starch (analyzed as reported by Bertrand et al., 2007).

${ }^{4} 4 \% \mathrm{FCM}=[0.40 \times$ milk yield $(\mathrm{kg} / \mathrm{d})]+[15 \times$ milk fat yield $(\mathrm{kg} / \mathrm{d})]$ (Gaines and Davidson, 1923).

${ }^{5} \mathrm{ECM}=[0.327 \times$ milk yield $(\mathrm{kg} / \mathrm{d})]+[12.95 \times$ fat yield $(\mathrm{kg} / \mathrm{d})]+[7.2 \times$ protein yield $(\mathrm{kg} / \mathrm{d})](\mathrm{Orth}, 1992)$.

range of 60 to $131 \mathrm{~g}$ of $\mathrm{NSC} / \mathrm{kg}$ of $\mathrm{DM}$ observed for fresh p.m.-cut alfalfa in a 3-yr study conducted over 7 growth cycles (Morin et al., 2012). A partly sunny day (i.e., daily global radiation of $21 \mathrm{MJ} / \mathrm{m}^{2}$ compared with a maximum of $29 \mathrm{MJ} / \mathrm{m}^{2}$ previously observed at the field site) before alfalfa cutting may have negatively affected the accumulation of NSC in alfalfa tissues in the present study. In fact, Watts (2008) reported that the concentration of NSC in p.m.-cut, mixed grass species was highly correlated with solar radiation on the day of sampling $(r=0.79)$. Nevertheless, the NSC concentration observed for the high-NSC alfalfa baleage was comparable to that of p.m.-cut alfalfa hays reported by Fisher et al. (2002; 53 to $56 \mathrm{~g}$ of $\mathrm{NSC} / \mathrm{kg}$ of DM) and
Burns et al. (2005; $46 \mathrm{~g}$ of NSC/kg of DM). In addition, the difference in NSC concentration between the highand low-NSC alfalfa baleages observed in the present experiment was comparable to that reported for alfalfa hays (i.e., 10 to $11 \mathrm{~g}$ of NSC/kg of DM; Fisher et al., 2002; Burns et al., 2005).

Concentrations of $\mathrm{Ca}, \mathrm{P}$, and $\mathrm{K}$ differed significantly between alfalfa baleages. Diets were balanced to meet animals' mineral requirements (NRC, 2001), and these small differences in $\mathrm{Ca}, \mathrm{P}$, and $\mathrm{K}$ appeared to have no effect on animal production as evidenced by similar milk yield and total DMI across treatments. Alfalfa baleage $\mathrm{pH}$ from the current study was very similar to that of alfalfa baleage (mean $\mathrm{pH}=5.9)$ and switchgrass 
Table 10. Effects of offering alfalfa baleage with different concentrations of NSC supplemented with a cornbased concentrate on plasma concentrations of AA in Holstein cows during early lactation ( $\mathrm{n}=10$ multiparous and 8 primiparous)

\begin{tabular}{|c|c|c|c|c|}
\hline \multirow[b]{2}{*}{ Item } & \multicolumn{2}{|c|}{ Diet } & \multirow[b]{2}{*}{$\mathrm{SED}^{1}$} & \multirow[b]{2}{*}{$P$-value ${ }^{2}$} \\
\hline & High NSC & Low NSC & & \\
\hline \multicolumn{5}{|l|}{ EAA } \\
\hline His, $\mu M$ & 46.1 & 46.2 & 3.1 & 0.98 \\
\hline Ile, $\mu M$ & 150 & 149 & 9.2 & 0.96 \\
\hline Leu, $\mu M$ & 171 & 166 & 9.6 & 0.66 \\
\hline Lys, $\mu M$ & 80.6 & 77.3 & 5.1 & 0.53 \\
\hline Met, $\mu M$ & 20.8 & 21.5 & 1.4 & 0.61 \\
\hline Lys:Met ratio & 3.9 & 3.7 & 0.22 & 0.27 \\
\hline Phe, $\mu M$ & 51.3 & 49.6 & 2.5 & 0.50 \\
\hline Thr, $\mu M$ & 102 & 105 & 6.7 & 0.68 \\
\hline Trp, $\mu M$ & 45.3 & 47.2 & 2.02 & 0.37 \\
\hline Val, $\mu M$ & 244 & 244 & 12.2 & 0.99 \\
\hline $\mathrm{BCAA},{ }^{3} \mu M$ & 564 & 559 & 30.4 & 0.88 \\
\hline Total, $\mu M$ & 910 & 904 & 38.2 & 0.88 \\
\hline \multicolumn{5}{|l|}{ NEAA } \\
\hline Ala, $\mu M$ & 237 & 239 & 10.1 & 0.82 \\
\hline Asn, $\mu M$ & 48.2 & 47.5 & 2.2 & 0.75 \\
\hline Asp, $\mu M$ & 21.4 & 15.5 & 1.0 & $<0.001$ \\
\hline Cys, $\mu M$ & 90.7 & 80.2 & 5.0 & 0.05 \\
\hline Gln, $\mu M$ & 260 & 273 & 12.1 & 0.31 \\
\hline Glu, $\mu M$ & 43.9 & 44.1 & 1.4 & 0.88 \\
\hline Gly, $\mu M$ & 348 & 336 & 12.5 & 0.40 \\
\hline Pro, $\mu M$ & 83.4 & 82.0 & 3.3 & 0.68 \\
\hline Ser, $\mu M$ & 78.0 & 76.2 & 4.5 & 0.69 \\
\hline Tyr, $\mu M$ & 58.1 & 57.4 & 3.1 & 0.84 \\
\hline Total, $\mu M$ & 1,268 & 1,251 & 34.7 & 0.62 \\
\hline Total AA ${ }^{4} \mu M$ & 2,179 & 2,157 & 65.4 & 0.75 \\
\hline
\end{tabular}

${ }^{1} \mathrm{SED}=$ standard error of the LSM difference.

${ }^{2}$ Probability of treatment (high- vs. low-NSC diet) effect; significance was declared at $P \leq 0.05$ and trends at $0.05<P \leq 0.10$.

${ }^{3} \mathrm{BCAA}=$ branched-chain AA (Ile + Leu + Val).

${ }^{4}$ Total AA $=$ total EAA + total NEAA.

baleage $\mathrm{pH}($ mean $\mathrm{pH}=5.8)$ reported by Brito at al. (2008) and Huntington and Burns (2007), respectively.

The decreased concentrations of individual organic acids (e.g., acetic and propionic acids) and total organic acids observed with the high-NSC alfalfa baleage are difficult to interpret based on current and previous results. Downing et al. (2008), evaluating the effects of forage WSC and cutting time on the fermentation characteristics of silages made from 4 perennial ryegrass (Lolium perenne L.) cultivars, reported that compared with a.m.-cut silage, p.m.-cut silage yielded significantly lower concentrations of individual and total organic acids. Similarly, Huntington and Burns (2007) reported higher concentrations of individual organic acids (e.g., acetic, propionic, and lactic) in a.m.- versus p.m.-cut switchgrass and gamagrass baleages. In the current study, out of 32 bales fed from d 14 to 21 in both sampling weeks, 20 bales were a.m.-cut and 12 bales were p.m.-cut, explaining to some extent the increased concentrations of individual and total organic acids with the low-NSC alfalfa baleage. However, based on current and previous studies (Huntington and Burns,
2007; Downing et al., 2008), the effect of diurnal cutting management on baleage and silage fermentation characteristics is difficult to reconcile and warrants further research. On the other hand, baleages fed in the present experiment were well preserved (McDonald et al., 1991), regardless of the differences in organic acid concentrations between treatments.

Overall, ruminal metabolism data from the present experiment should be interpreted cautiously in light of the lack of difference in total NSC intake between treatments but significantly increased fiber (i.e., NDF and $\mathrm{ADF}$ ) and $\mathrm{N}$ intakes in cows fed the low-NSC diet. Mean ruminal $\mathrm{pH}$ tended to decrease in cows fed highNSC diet, and as a result of a significant sampling time $\times$ treatment interaction, it was lowest at 0800,1000 , 1700 , and $2000 \mathrm{~h}$ in the high-NSC diet. In addition, when 4 of the 8 ruminally cannulated cows were fitted with indwelling ruminal $\mathrm{pH}$ electrodes $(\mathrm{pH}$ readings every $5 \mathrm{~min}$ ), the proportion of daily time in which ruminal $\mathrm{pH}$ was below 6.0 (38 vs. $13.3 \% / \mathrm{d})$ and $5.6(16.4$ vs. $0.6 \% / d$ ) tended to be or was significantly higher when feeding the high-NSC diet (Régimbald et al., 
2009). The amount of TESC digested in the rumen was highest $(+21 \% ; P<0.001$; data not shown) in cows fed the high-NSC diet, which could explain the differences in ruminal $\mathrm{pH}$ between treatments in the current study. Interestingly, ruminal $\mathrm{pH}$ obtained immediately before cows were fed their first concentrate meal (i.e., $1000 \mathrm{~h}$ ) or $1 \mathrm{~h}$ after they were offered forage (i.e., $0900 \mathrm{~h}$ ) was decreased when feeding the high-NSC alfalfa baleage. Thus, we can hypothesize that during the time elapsed between the forage meal and the first concentrate meal, the high-NSC alfalfa baleage was either consumed more or consumed faster. In fact, beef steers fed p.m.-cut rather than a.m.-cut switchgrass or gamagrass baleage spent significantly more time eating and less time resting during meals (Huntington and Burns, 2007), which agrees with Gregorini et al. (2006, 2008), who reported longer and more intense grazing bouts in beef cattle grazing pasture in the afternoon. Alternatively, ruminal degradation rate and effective degradability of NSC may have been increased with feeding the high-NSC alfalfa baleage. For instance, Yari et al. (2012b) showed that the effective degradability of total carbohydrates in the rumen tended to be higher in the p.m.-cut alfalfa hay compared with the a.m. counterpart.

Increased intake of NDF in alfalfa hay-based diets ranging from 310 to $370 \mathrm{~g}$ of $\mathrm{NDF} / \mathrm{kg}$ of DM linearly increased milk fat concentration and mean ruminal $\mathrm{pH}$, and linearly decreased the amount of time in which ruminal $\mathrm{pH}$ was below 6.0 in early-lactation dairy cows (Beauchemin, 1991). Similarly, Dado and Allen (1995) observed increased mean ruminal $\mathrm{pH}$ and rumination time, and decreased amount of time in which ruminal $\mathrm{pH}$ was below 6.0 in early-lactation dairy cows fed alfalfa plus corn silage-based diets with high (352 g of $\mathrm{NDF} / \mathrm{kg}$ of $\mathrm{DM}$ ) versus low (257 g of $\mathrm{NDF} / \mathrm{kg}$ of DM) $\mathrm{NDF}$ concentration. Intake of NDF was increased $(P$ $<0.01$ ) in the 8 ruminally cannulated cows fed the low-NSC $(7.0 \mathrm{~kg} / \mathrm{d})$ rather than the high-NSC diet $(6.6$ $\mathrm{kg} / \mathrm{d}$; data not shown), further explaining the positive effect of the low-NSC diet on ruminal $\mathrm{pH}$ in the current study.

It was surprising to find that the mean concentration of ruminal $\mathrm{NH}_{3}-\mathrm{N}$ was highest when feeding the highNSC diet, particularly because $\mathrm{N}$ intake was lowest in cows fed this ration. For instance, when lactating dairy cows were fed diets with incremental concentrations of $\mathrm{CP}$, both $\mathrm{N}$ intake (from 483 to $711 \mathrm{~g} / \mathrm{d}$ ) and ruminal $\mathrm{NH}_{3}-\mathrm{N}$ (from 6.10 to $12.8 \mathrm{mg} / \mathrm{dL}$ ) increased linearly (Olmos Colmenero and Broderick, 2006). A significant sampling time $\times$ treatment interaction was observed, indicating that cows fed the high-NSC diet showed increased concentrations of ruminal $\mathrm{NH}_{3}-\mathrm{N}$ at 1100 and 1200 h. Yari et al. (2012a,b) reported no effect of cutting time (p.m.- vs. a.m.-cutting) on effective degrad- ability and fractional degradation rate of $\mathrm{N}$ when alfalfa hays were incubated in the rumen of 3 nonpregnant dry Holstein-Friesian cows. Overall, neither ruminal N degradation kinetics (Yari et al., 2012a,b) nor N intake appears to provide a reasonable explanation for the significant differences in ruminal $\mathrm{NH}_{3}-\mathrm{N}$ observed in the present experiment. Therefore, additional factors such as unrepresentative ruminal sampling and analytical errors should not be ruled out.

The molar proportion of ruminal valerate, a branchedchain VFA, was highest when feeding the low-NSC diet. Ruminal branched-chain VFA originate primarily from dietary true protein degradation, but they can also originate through microbial protein recycling (Miura et al., 1980). Nitrogen apparently digested in the rumen increased in cows offered the low-NSC diet, possibly explaining the observed increase in ruminal valerate. The molar proportion of ruminal propionate tended to be reduced when feeding the high-NSC diet, thus disagreeing with previous research that showed a shift in ruminal metabolism toward propionate formation as a result of feeding high-NSC forage (Lee et al., 2002; Berthiaume et al., 2010). It must be noted that neither NSC intake nor OM truly digested in the rumen differed significantly between treatments, thus indicating that similar amounts of fermentable energy were available to microbes in the rumen.

Because the ruminal digestibility of $\mathrm{OM}$ did not differ significantly between treatments, the enhanced total-tract digestibility (\% of intake) of OM when feeding the high-NSC diet is entirely explained by increased postruminal OM digestibility. Postruminal digestibility of NDF tended to increase whereas that of $\mathrm{ADF}$ significantly increased in cows fed the high-NSC diet (data not shown). Previous research showed that cecal and colonic fermentation account for 8.6 to $16.8 \%$ of the total VFA production in ruminants (Ulyatt et al., 1975), with cecal VFA contributing to an average of $8.6 \%$ of the ME intake in steers fed diets with different forage-to-concentrate ratios (Siciliano-Jones and Murphy, 1989). Thus, increased postruminal digestibility of fiber with feeding the high-NSC diet likely contributed to the ME pool used to meet milk production requirements. Similar to the current results, Yari et al. (2014) observed increased apparent total-tract digestibilities for both DM and OM in cows fed TMR consisting of p.m.- versus a.m.-cut alfalfa hay supplemented with $15 \%$ barley silage, and $65 \%$ concentrate.

A significant decrease in $\mathrm{N}$ intake coincided with a decreased concentration of $\mathrm{N}$ in the high-NSC alfalfa baleage. Nitrogen apparently digested in the rumen also decreased when feeding the high-NSC diet, possibly in response to reduced ruminal $\mathrm{pH}$. Ruminal $\mathrm{pH}$ remained below 5.6 for a longer period when feeding 
the high- versus the low-NSC diet (Régimbald et al., 2009), likely depressing the proteolytic activity of ruminal microorganisms. Although the optimal $\mathrm{pH}$ for ruminal proteolytic enzymes ranges from 5.5 to 7.0, protein degradation is reduced at the lower end of this range (Kopecny and Wallace, 1982). For instance, proteolytic microorganisms were dramatically reduced (from 0.5 to $1.0 \times 10^{8}$ cells $/ \mathrm{mL}$ to $<1.0 \times 10^{4}$ cells/ $\mathrm{mL}$ ) in continuous culture when $\mathrm{pH}$ was changed from 6.0-7.0 to 5.5 (Erfle et al., 1982). Moreover, protein degradation was reduced as $\mathrm{pH}$ decreased from 7.0 to 4.9 in diets with high forage or high concentrate during continuous culture fermentation (Calsamiglia et al., 2008). Depressed ruminal N digestibility in cows fed the high-NSC diet was compensated for by enhanced digestion of $\mathrm{N}$ postrumen resulting in no difference in apparent total-tract $\mathrm{N}$ digestibility between treatments.

Omasal flows of PAB, FAB, and total bacteria were not increased with feeding the high-NSC diet, possibly as a result of no difference in DMI and OM intake between treatments. In fact, Oldick et al. (1999) and Clark et al. (1992) reported, respectively, positive relationships between DMI and OM intakes and passage of bacterial $\mathrm{N}$ to the small intestine in dairy cows. Reduced $\mathrm{N}$ intake in addition to increased ruminal digestibility of TESC might explain the improved efficiency of bacterial protein synthesis when expressed as grams of total bacterial NAN per gram of RDP-N supply. The absence of a dietary treatment effect on omasal flow of AA was not surprising based on the lack of differences in non- $\mathrm{NH}_{3}$ nonbacterial $\mathrm{N}$, and bacterial NAN flows. Overall, $\mathrm{N}$ utilization was not improved by feeding the high-NSC diet, thus limiting the potential to reduce environmental $\mathrm{N}$ pollution under the conditions of the present study.

The observed reduction in forage DMI, when all 18 cows were used in the statistical analysis, with feeding the high-NSC alfalfa baleage was unexpected particularly because previous results have shown that p.m.-cut alfalfa baleage significantly improved DMI in late-lactation dairy cows fed an exclusively forage diet (Brito et al., 2008). Fisher et al. (2002) and Burns et al. (2005) showed that different ruminant species (e.g., steers, goats, and sheep) preferred p.m.- over a.m.-cut alfalfa hay as their only dietary sources, resulting in improved short-term DMI even when the difference in NSC concentration was as small as $10 \mathrm{~g}$ of NSC $/ \mathrm{kg}$ of DM. Although the difference in NSC concentration between alfalfa baleages was similar to that reported previously (Fisher et al., 2002; Burns et al., 2005), cows consumed significantly less high-NSC alfalfa baleage, suggesting that high concentrate feeding may have negatively affected forage DMI. On the other hand, Taweel et al. (2005) reported that forage DMI was not affected by feeding lactating dairy cows high- versus low-WSC fresh perennial ryegrass supplemented with a low amount of concentrate (80:20 forage-to-concentrate ratio) despite a difference of $28 \mathrm{~g}$ of $\mathrm{WSC} / \mathrm{kg}$ of $\mathrm{DM}$ between forage sources. Recently, Yari et al. (2014) reported that mean DMI was not affected when dairy cows in early lactation were fed TMR containing $20 \%$ of p.m.- or a.m.-cut alfalfa hay supplemented with a high proportion of concentrate. Results from Yari et al. (2014) suggest that either the proportion of p.m.cut alfalfa hay included in the TMR was too low to elicit a positive response in DMI or that concentrate level interacted with forage quality, masking the potential beneficial effect of p.m.-cut alfalfa hay on DMI. In addition, Yari et al. (2014) reported a trend and a significant cutting time $\times$ stage of maturity (early bud, late bud, and early flower) interaction for $\mathrm{OM}$ and $\mathrm{CP}$ intakes, respectively, indicating that the effect of diurnal cutting management on nutrient intake depends on the stage of maturity at which the forage is harvested. Because the plant stage of maturity appears to interact with diurnal cutting management or forage NSC to modulate intake, it is conceivable that cutting alfalfa at the full flowering stage of development and harvesting it as baleage may have influenced forage DMI in the current study. On the other hand, one could hypothesize that reduced NSC concentration may have stimulated cows to increase intake of the lowNSC alfalfa baleage to meet the high ME demand for milk production, particularly during early lactation.

The lack of difference in milk production between treatments is likely explained by increased fiber intake (i.e., NDF and ADF) in cows fed the low-NSC diet and the high amount of concentrate fed. When dietary concentrate level ranged from $47 \%$ (current study) to $65 \%$ (Yari et al., 2014), milk production was not improved in response to high-NSC alfalfa baleage or high-NSC alfalfa hay, respectively. However, feeding high-NSC alfalfa baleage or high-WSC perennial ryegrass with no (Brito et al., 2008) or low concentrate supplementation ( $\leq 23 \%$ of diet DM; Miller et al., 2001; Moorby et al., 2006) resulted in milk production improvements of up to $2.3 \mathrm{~kg} / \mathrm{d}$.

As discussed earlier, the proportion of daily time for which ruminal $\mathrm{pH}$ was below 6.0 and 5.6 during a 24 -h period was increased in cows fed the high-NSC diet (Régimbald et al., 2009). An extended amount of time with $\mathrm{pH}$ below 6.0 and 5.6 may have induced incomplete ruminal biohydrogenation of dietary unsaturated FA (Bauman and Griinari, 2001), which could explain the observed reduction in milk fat concentration and reduced 4\% FCM and ECM in cows fed the high-NSC diet (Table 9). In addition, NDF intake was significantly reduced in cows fed the high-NSC diet, further 
explaining the reduction in milk fat. Previous research showed that increased NDF intake was associated with increased rumination time, milk fat concentration, and ruminal pH (Beauchemin, 1991; Dado and Allen, 1995). It is well established that chewing stimulates saliva production, which can increase the buffering capacity of the rumen and prevents low ruminal $\mathrm{pH}$ and reduction in milk fat concentration (Mertens, 1997).

Concentrations of PUN $(P=0.08)$ followed that of MUN and decreased when feeding the high-NSC diet. It is well established that concentration of BUN directly affects that of MUN (Oltner and Wiktorsson, 1983; Roseler et al., 1993) because urea freely diffuses from blood to milk (Gustafsson and Palmquist, 1993). Kauffman and St. Pierre (2001) reported a positive relationship $\left(\mathrm{R}^{2}=0.84\right)$ between MUN and PUN using Holstein and Jersey cows fed diets with different concentrations of CP and NDF. Reduced concentrations of PUN and MUN are entirely explained by decreased $\mathrm{N}$ intake in cows fed the high-NSC diet. In fact, $\mathrm{N}$ intake, PUN, and MUN all increased linearly in lactating dairy cows fed diets with incremental levels of $\mathrm{CP}$ (Olmos Colmenero and Broderick, 2006).

Plasma concentrations of the NEAA Asp and Cys were significantly decreased when feeding the low-NSC diet. It is well documented that the urea cycle consumes an amino group from Asp, with the remaining carbon skeleton used for energy (citric acid cycle) and gluconeogenesis (Lobley et al., 1995). Therefore, the observed reduction in the plasma concentration of Asp with the low-NSC diet may be related to its use for ureagenesis in the liver. It is important to note that the concentration of PUN tended to increase in cows fed the low-NSC diet, suggesting utilization of the Asp amino group for urea synthesis in the urea cycle. Ahmed and Bergen (1983) reported that as much as $58 \%$ of the total sulfur AA requirements of growing cattle can be met by Cys and its oxidation product cystine, but no reports to date have established similar relationship in lactating dairy cows. In the current study, the $12 \%$ reduction in the plasma concentration of Cys with feeding the low-NSC diet did not affect plasma Met or the Lys:Met ratio. Overall, reduced plasma concentrations of both Asp and Cys in cows fed the low-NSC diet likely had minor or no effect on $\mathrm{N}$ utilization because the similar NSC intake between treatments did not affect the plasma concentrations of total EAA and total NEAA. According to the NRC (2001), if individual NEAA are in short supply relative to an animal's metabolic needs, they can be synthesized from one another or from individual EAA supplied in excess of requirements.

\section{CONCLUSIONS}

Overall, results from the current study should be interpreted cautiously because of the lack of difference in dietary NSC intake between treatments and the decreased NDF, ADF, and $\mathrm{N}$ intakes in cows fed the high-NSC diet. Feeding diets containing alfalfa baleage with contrasting NSC concentrations supplemented with a common corn-based concentrate to earlylactation dairy cows did not improve milk production and bacterial protein synthesis possibly because (1) the NSC concentration of the high-NSC alfalfa baleage decreased substantially in the time elapsed between baling and the beginning of the study; (2) total (i.e., forage plus concentrate) DMI and NSC intake did not differ significantly between treatments; (3) the difference in NSC concentration between alfalfa baleages was small (i.e., $14 \mathrm{~g}$ of $\mathrm{NSC} / \mathrm{kg}$ of DM); and (4) the amount of concentrate fed (approximately $10 \mathrm{~kg}$ per cow/d) provided enough ruminally fermentable energy to meet microbial and animal requirements, thus diluting the contribution of forage NSC to total dietary NSC. The observed reduction in milk fat concentration and consequent reductions in 4\% FCM and ECM in cows fed the high-NSC diet may be explained by increased proportion of daily time in which ruminal $\mathrm{pH}$ was below 6.0 and 5.6, and by the decreased NDF and ADF intakes. In general, $\mathrm{N}$ utilization was not improved and decreased MUN and PUN are entirely explained by reduced $\mathrm{N}$ intake in cows fed the high-NSC diet. Thus, under the conditions of the current study, we conclude that the high-NSC alfalfa baleage/high-NSC diet was not effective in mitigating $\mathrm{N}$ pollution as demonstrated by similar urinary excretions of $\mathrm{N}$ and urea $\mathrm{N}$ as well as similar milk $\mathrm{N}$ efficiency compared with the lowNSC alfalfa baleage/low-NSC diet. Further research is warranted to determine the minimal increase in forage NSC concentration needed to improve animal performance. Furthermore, the effects of supplementing highNSC forage with different concentrate levels and type of concentrate should be also investigated.

\section{ACKNOWLEDGMENTS}

The authors gratefully thank Sylvie Provencher, Pamela Warburton, and Jocelyne Renaud for sample collection and laboratory analyses at the Dairy and Swine Research and Development Centre in Sherbrooke. The assistance of Mario Laterrière and Josée Bourassa from the Soils and Crops Research and Development in Québec City for preparation and chemical analyses of forage used in this study is also acknowledged. The statistical 
advice of Steve Méthot (Dairy and Swine Research and Development Centre, Sherbrooke) is gratefully acknowledged. The authors also thank Keith Carter and the barn crew for animal care and sampling at the Dairy and Swine Research and Development Centre Farm and the Normandin Research Farm crew for cropping services. Appreciation is extended to Agriculture and Agri-Food Canada for the financial support.

\section{REFERENCES}

Ahmed, B. M., and W. G. Bergen. 1983. Methionine-cyst(e)ine relationship in steers. J. Anim. Sci. 57(Suppl. 1):110. (Abstr.)

Ahvenjärvi, S., A. Vanhatalo, P. Huhtanen, and T. Varvikko. 2000. Determination of reticulo-rumen and whole-stomach digestion in lactating cows by omasal canal or duodenal sampling. Br. J. Nutr. 83:67-77.

AOAC International. 2000. Official Methods of Analysis. 17th ed. AOAC International, Arlington, VA.

AOAC International. 2006. Official Methods of Analyses. 18th ed. AOAC International, Gaithersburg, MD.

Bauman, D. E., and J. M. Griinari. 2001. Regulation and nutritional manipulation of milk fat: Low-fat milk syndrome. Livest. Prod. Sci. $70: 15-29$.

Beauchemin, K. A. 1991. Effects of dietary neutral detergent fiber concentration and alfalfa hay quality on chewing, rumen function, and milk production of dairy cows. J. Dairy Sci. 74:3140-3151.

Berthiaume, R., C. Benchaar, A. V. Chaves, G. F. Tremblay, Y. Castonguay, A. Bertrand, G. Bélanger, R. Michaud, C. Lafrenière, T. McAllister, and A. F. Brito. 2010. Increasing nonstructural carbohydrates in alfalfa improves in vitro microbial $\mathrm{N}$ synthesis. J. Dairy Sci. 93:693-700.

Bertrand, A., D. Prévost, F. J. Bigras, and Y. Castonguay. 2007. Elevated atmospheric $\mathrm{CO}_{2}$ and strain of rhizobium alter freezing tolerance and cold-induced molecular changes in alfalfa (Medicago sativa L.). Ann. Bot. 99:275-284.

Bigras, F. J., and A. Bertrand. 2006. Responses of Picea mariana to elevated $\mathrm{CO}_{2}$ concentration during growth, cold hardening and dehardening: Phenology, cold tolerance, photosynthesis and growth. Tree Physiol. 26:875-888.

Blakeney, A. B., and L. L. Mutton. 1980. A simple colorimetric method for the determination of sugar in fruit and vegetables. J. Sci. Food Agric. 31:889-897.

Borucki Castro, S. I., L. E. Phillip, H. Lapierre, P. W. Jardon, and R. Berthiaume. 2007. Ruminal degradability and intestinal digestibility of protein and amino acids in treated soybean meal products. J. Dairy Sci. 90:810-822.

Brito, A. F., and G. A. Broderick. 2006. Effect of varying dietary ratios of alfalfa silage to corn silage on production and nitrogen utilization in lactating dairy cows. J. Dairy Sci. 89:3924-3938.

Brito, A. F., G. F. Tremblay, H. Lapierre, A. Bertrand, Y. Castonguay, G. Bélanger, R. Michaud, C. Benchaar, D. R. Ouellet, and R. Berthiaume. 2009. Alfalfa cut at sundown increases bacterial protein synthesis in late-lactation dairy cows. J. Dairy Sci. 92:1092-1107.

Brito, A. F., G. F. Tremblay, D. R. Ouellet, A. Bertrand, Y. Castonguay, G. Bélanger, R. Michaud, H. Lapierre, and R. Berthiaume. 2008. Alfalfa cut at sundown and harvested as baleage improves milk yield of late-lactation dairy cows. J. Dairy Sci. 91:3968-3982.

Burns, J. C., H. F. Mayland, and D. S. Fisher. 2005. Dry matter intake and digestion of alfalfa harvested at sunset and sunrise. J. Anim. Sci. 83:262-270.

Calder, A. G., K. E. Garden, S. E. Anderson, and G. E. Lobley. 1999. Quantification of blood and plasma amino acids using isotope dilution electron impact gas chromatography/mass spectrometry with $\mathrm{U}^{13}{ }^{13} \mathrm{C}$ amino acids as internal standards. Rapid Commun. Mass Spectrom. 13:2080-2083.

Calsamiglia, S., P. W. Cardozo, A. Ferret, and A. Bach. 2008. Changes in rumen microbial fermentation are due to a combined effect of type of diet and pH. J. Anim. Sci. 86:702-711.
Canadian Council on Animal Care. 1993. Guide to the Care and Use of Experimental Animals. Vol. 1. E. D. Offert, B. M. Cross, and A. A. McWilliam, ed. CCAC, Ottawa, Ontario.

Clark, J. H., T. H. Klusmeyer, and M. R. Cameron. 1992. Microbial protein synthesis and flows of nitrogen fractions to the duodenum of dairy cows. J. Dairy Sci. 75:2304-2323.

Cochran, R. C., D. C. Adams, J. D. Wallace, and M. L. Galyean. 1986. Predicting digestibility of different diets with internal markers: Evaluation of four potential markers. J. Anim. Sci. 63:1476-1487.

Dado, R. G., and M. S. Allen. 1995. Intake limitations, feeding behavior, and rumen function of cows challenged with rumen fill from dietary fiber or inert bulk. J. Dairy Sci. 78:118-133.

Delbecchi, L., C. E. Ahnadi, J. J. Kennelly, and P. Lacasse. 2001. Milk fatty acid composition and mammary lipid metabolism in Holstein cows fed protected or unprotected canola seeds. J. Dairy Sci. 84:1375-1381.

Downing, T. W., A. Buyserie, M. Gamroth, and P. French. 2008. Effect of water-soluble carbohydrates on fermentation characteristics of ensiled perennial ryegrass. Prof. Anim. Sci. 24:35-39.

Dubois, M., K. A. Gilles, J. K. Hamilton, P. A. Rebers, and F. Smith. 1956. Colorimetric method for determination of sugars and related substances. Anal. Chem. 28:350-356.

Erfle, J. D., R. J. Boila, R. M. Teather, S. Mahadevan, and F. D. Sauer. 1982. Effect of $\mathrm{pH}$ on fermentation characteristics and protein degradation by rumen microorganisms in vitro. J. Dairy Sci. 65:1457-1464.

Fisher, D. S., H. F. Mayland, and J. C. Burns. 2002. Variation in ruminant preference for alfalfa hays cut at sunup and sundown. Crop Sci. 42:231-237.

France, J., and R. C. Siddons. 1986. Determination of digesta flow by continuous marker infusion. J. Theor. Biol. 121:105-120.

Gaines, W. L., and F. A. Davidson. 1923. Relation between percentage fat content and yield of milk. Bull. 245. Ill. Agric. Expt. Sta., University of Illinois, Urbana.

Gregorini, P., M. Eirin, R. Refi, M. Ursino, O. E. Ansin, and S. A. Gunter. 2006. Timing of herbage allocation in strip grazing: Effects on grazing pattern and performance of beef steers. J. Anim. Sci. 84:1943-1950.

Gregorini, P., S. A. Gunter, and P. A. Beck. 2008. Matching plant and animal processes to alter nutrient supply in strip-grazed pasture: Timing of herbage and fasting allocation. J. Anim. Sci. 86:10061020 .

Gustafsson, A. H., and D. C. Palmquist. 1993. Diurnal variation of rumen ammonia, serum urea, and milk urea in dairy cows at high and low yields. J. Dairy Sci. 76:475-484.

Hall, M. B. 2000. Neutral detergent-soluble carbohydrates: Nutritional relevance and analysis. A laboratory manual. Ext. Bull. 339. University of Florida, Gainesville.

Hall, M. B., W. H. Hoover, J. P. Jennings, and T. K. M. Webster. 1999. A method for partitioning neutral detergent soluble carbohydrates. J. Sci. Food Agric. 79:2079-2086.

Holm, J., I. Bjorck, A. Drews, and N. G. Asp. 1986. A rapid method for the analysis of starch. Starke 38:224-226.

Huhtanen, P., P. G. Brotz, and L. D. Satter. 1997. Omasal sampling technique for assessing fermentative digestion in the forestomach of dairy cows. J. Anim. Sci. 75:1380-1392.

Huhtanen, P., K. Kaustell, and S. Jaakkola. 1994. The use of internal markers to predict total digestibility and duodenal flow of nutrients in cattle given six different diets. Anim. Feed Sci. Technol. 48:211-227.

Huntington, G. B., and J. C. Burns. 2007. Afternoon harvest increases readily fermentable carbohydrate concentration and voluntary intake of gamagrass and switchgrass baleage by beef steers. J. Anim. Sci. 85:276-284.

Karkalas, J. J. 1985. An improved enzymatic method for the determination of native and modified starch. J. Sci. Food Agric. $36: 1019-1027$.

Kauffman, A. J., and N. R. St-Pierre. 2001. The relationship of milk urea nitrogen to urine nitrogen excretion in Holstein and Jersey cows. J. Dairy Sci. 84:2284-2294. 
Kopecny, J., and R. J. Wallace. 1982. Cellular location and some properties of proteolytic enzymes of rumen bacteria. Appl. Environ. Microbiol. 43:1026-1033.

Krause, K. M., and G. R. Oetzel. 2006. Understanding and preventing subacute ruminal acidosis in dairy herds: A review. Anim. Feed Sci. Technol. 126:215-236.

Lee, M. R. F., L. J. Harris, J. M. Moorby, M. O. Humphreys, M. K. Theodorou, J. C. MacRae, and N. D. Scollan. 2002. Rumen metabolism and nitrogen flow to the small intestine in steers offered Lolium perenne containing different levels of water-soluble carbohydrate. Anim. Sci. 74:587-596.

Licitra, G., T. M. Hernandez, and P. J. Van Soest. 1996. Standardization of procedures for nitrogen fractionation of ruminant feeds. Anim. Feed Sci. Technol. 57:347-358.

Lobley, G. E., A. Connell, M. A. Lomax, D. S. Brown, E. Milne, A. G. Calder, and D. A. H. Farningham. 1995. Hepatic detoxification of ammonia in the ovine liver: Possible consequences for amino acid catabolism. Br. J. Nutr. 73:667-685.

Martineau, R., H. Lapierre, D. R. Ouellet, D. Pellerin, and R. Berthiaume. 2007. Effects of method of conservation of timothy on nitrogen metabolism in lactating dairy cows. J. Dairy Sci. 90:2870-2882.

McCutcheon, S. N., and D. E. Bauman. 1986. Effect of chronic growth hormone treatment on response to epinephrine and thyrotropinreleasing hormones in lactating cows. J. Dairy Sci. 69:44-51.

McDonald, P., A. R. Henderson, and S. J. E. Heron. 1991. The Biochemistry of Silage. J. Wiley and Sons, New York, NY.

McManus, M. T., R. L. Bieleski, J. R. Caradus, and D. J. Barker. 2000. Pinitol accumulation in immature leaves of white clover in response to a water deficit. Environ. Exp. Bot. 43:11-18.

Mertens, D. R. 1997. Creating a system for meeting the fiber requirements of dairy cows. J. Dairy Sci. 80:1463-1481.

Miller, L. A., J. M. Moorby, D. R. Davies, M. O. Humphreys, N. D. Scollan, J. C. MacRae, and M. K. Theodorou. 2001. Increased concentration of water-soluble carbohydrate in perennial ryegrass (Lolium perenne L.): Milk production from late-lactation dairy cows. Grass Forage Sci. 56:383-394.

Miura, H., M. Horiguchi, and T. Matsumoto. 1980. Nutritional interdependence among rumen bacteria, Bacteroides amylphilius, Megasphaera elsdenii, and Ruminococcus albus. Appl. Environ. Microbiol. 40:294-300.

Moorby, J. M., R. T. Evans, N. D. Scollan, J. C. MacRae, and M. K. Theodorou. 2006. Increased concentration of water-soluble carbohydrate in perennial ryegrass (Lolium perenne L.). Evaluation in dairy cows in early lactation. Grass Forage Sci. 61:52-59.

Morin, C., G. Bélanger, G. F. Tremblay, A. Bertrand, Y. Castonguay, R. Drapeau, R. Michaud, R. Berthiaume, and G. Allard. 2011. Diurnal variations of nonstructural carbohydrates and nutritive value in alfalfa. Crop Sci. 51:1297-1306.

Morin, C., G. F. Tremblay, G. Bélanger, A. Bertrand, Y. Castonguay, R. Drapeau, R. Michaud, R. Berthiaume, and G. Allard. 2012. Nonstructural carbohydrate concentration during field wilting of PM- and AM-cut alfalfa. Agron. J. 104:649-660.

NRC. 2001. Nutrient Requirements of Dairy Cattle. 6th rev. ed. Natl. Acad. Sci., Washington, DC.

Novozamsky, I., R. van Eck, J. C. van Schouwenburg, and I. Walinga. 1974. Total nitrogen determination in plant material by means of the indophenol-blue method. Neth. J. Agric. Sci. 22:3-5.

Oldick, B. S., J. L. Firkins, and N. R. St-Pierre. 1999. Estimation of microbial nitrogen flow to the duodenum of cattle based on dry matter intake and diet composition. J. Dairy Sci. 82:1497-1511.

Olmos Colmenero, J. J., and G. A. Broderick. 2006. Effect of dietary crude protein concentration on milk production and nitrogen utilization in lactating dairy cows. J. Dairy Sci. 89:1704-1712.

Oltner, R., and H. Wiktorsson. 1983. Urea concentrations in milk and blood as influenced by feeding varying amounts of protein and energy to dairy cows. Livest. Prod. Sci. 10:457-467.

Orth, R. 1992. Sample Day and Lactation Report. DHIA 200 FactSheet A-2. Mid-States Dairy Records Processing Center, Ames, IA.

Régimbald, G., V. Girard, A. F. Brito, G. Allard, D. Pellerin, G. F. Tremblay, and R. Berthiaume. 2009. Effects of high non-struc- tural carbohydrate concentration in lucerne on feeding behaviour and ruminal $\mathrm{pH}$ of early lactating cows. XI Int. Symp. Ruminant Physiology, Clermont-Ferrand, France. Pages 340-342 in Ruminant Physiology, Digestion, Metabolism, and Effects of Nutrition on Reproduction and Welfare. Wageningen Academic Publishers, Wageningen, the Netherlands.

Reynal, S. M., and G. A. Broderick. 2005. Effect of dietary level of rumen-degraded protein on production and nitrogen metabolism in lactating dairy cows. J. Dairy Sci. 88:4045-4064.

Reynal, S. M., G. A. Broderick, S. Ahvenjärvi, and P. Huhtanen. 2003. Effect of feeding protein supplements of differing degradability on omasal flow of microbial and undegraded protein. J. Dairy Sci. $86: 1292-1305$.

Roseler, D. K., J. D. Ferguson, C. J. Sniffen, and J. Herrema. 1993. Dietary protein degradability effects on plasma and milk urea nitrogen and milk nonprotein nitrogen in Holstein cows. J. Dairy Sci. $76: 525-534$.

Siciliano-Jones, J., and M. R. Murphy. 1989. Cecum-colon of steers as affected by forage:concentrate and forage physical form. J. Dairy Sci. 72:485-492.

Siddons, R. C., J. Paradine, D. E. Beever, and P. R. Cornell. 1985 Ytterbium acetate as a particulate-phase digesta-flow marker. $\mathrm{Br}$. J. Nutr. 54:509-519.

Smith, A. E., and D. V. Phillips. 1980. Occurrence of pinitol in foliage of several forage legume species. Crop Sci. 20:75-77.

Streeter, J. G., D. G. Lohne, and R. J. Fioritto. 2001. Patterns of pinitol accumulation in soybean plants and relationships to drought tolerance. Plant Cell Environ. 24:429-438.

Taweel, H. Z., B. M. Tas, H. J. Smit, A. Elgersma, J. Dijkstra, and S. Tamminga. 2005. Effects of feeding perennial ryegrass with an elevated concentration of water-soluble carbohydrates on intake, rumen function and performance of dairy cows. Anim. Feed Sci. Technol. 121:243-256.

Udén, P., P. E. Colucci, and S. P. J. Van. 1980. Investigation of chromium, cerium and cobalt as markers in digesta: Rate of passage studies. J. Sci. Food Agric. 31:625-632.

Ulyatt, M. J., D. W. Dellow, C. S. W. Reid, and T. Bauchop. 1975. Structure and function of the large intestine of ruminants. Digestion and metabolism in the ruminant. I. W. McDonald and A. C. I. Warner, ed. Proc. IV Int. Symp. Ruminant Physiol., Univ. New England Publ., Armidale, Australia.

Valadares, R. F. D., G. A. Broderick, S. C. Valadares Filho, and M. K. Clayton. 1999. Effect of replacing alfalfa silage with high moisture corn on ruminal protein synthesis estimated from excretion of total purine derivatives. J. Dairy Sci. 82:2686-2696.

Van Keulen, J., and B. A. Young. 1977. Evaluation of acid-insoluble ash as a natural marker in ruminant digestibility studies. J. Anim. Sci. $44: 282-287$.

Van Soest, P. J., J. B. Robertson, and B. A. Lewis. 1991. Methods for dietary fiber, neutral detergent fiber, and nonstarch polysaccharides in relation to animal nutrition. J. Dairy Sci. 74:3583-3597.

Watts, K. 2008. The influence of solar radiation and temperature on the diurnal fluctuation of NSC in grass. Accessed May 5, 2013. http://www.safergrass.org/pdf/DiurnalFluctCHO.pdf.

Yari, M., R. Valizadeh, A. A. Naserian, G. R. Ghorbani, P. Rezvani Moghaddam, A. Jonker, and P. Yu. 2012a. Botanical traits, protein and carbohydrate fractions, ruminal degradability and energy contents of alfalfa hay harvested at three stages of maturity and in the afternoon and morning. Anim. Feed Sci. Technol. 172:162-170.

Yari, M., R. Valizadeh, A. A. Naserian, A. Jonker, A. Azarfard, and P. Yu. 2014. Effects of including alfalfa hay cut in the afternoon or morning at three stages of maturity in high concentrate rations on dairy cows' performance, diet digestibility and feeding behavior. Anim. Feed Sci. Technol. 192:62-72.

Yari, M., R. Valizadeh, A. A. Naserian, A. Jonker, and P. Yu. 2012b. Modeling nutrient availability of alfalfa hay harvested at three stages of maturity and in the afternoon and morning in dairy cows. Anim. Feed Sci. Technol. 178:12-19. 